\title{
Kuzey Anadolu Fay Zonu'nun Tosya-Kargl-Kamil Arasındaki Kesiminde Akarsu Havzalarının Rölatif Tektonik Aktivite Düzeylerinin Jeomorfometrik Yöntemlerle Belirlenmesi
}

\section{Determination of Relative Tectonic Activity Levels of Stream Basins in the Part of the North Anatolian Fault Zone between Tosya-Kargl-Kamil by Geomorphometric Methods}

\author{
Mustafa ARIKAN ${ }^{1}$ (D), T. Ahmet ERTEK ${ }^{2}$ (D) \\ ${ }^{1}$ Dr., Konya Meram İbrahim Ethem Kız Anadolu İmam Hatip Lisesi, Coğrafya Öğretmeni, Konya, Türkiye \\ ${ }^{2}$ Doç.Dr., İstanbul Üniversitesi Edebiyat Fakültesi Coğrafya Bölümü, İstanbul, Türkiye
}

ORCID: M.A 0000-0002-1929-629X; T.A.E 0000-0002-9857-4832

\begin{abstract}
öz
Kuzey Anadolu Fay (KAF) Zonu'nun orta kesiminde, Tosya-Kargı arasında GB-KD yönlü uzanan, fay kontrolünde gelişen, Devrez Çayı Vadisi ile Kargı-Kamil arasında yine fay kontrolünde gelişen, B-D uzanımlı Kızılırmak Vadisi yer alır. Her iki kesimde yamaçlardan ana akarsulara bağlanan yan dereler, KAF Zonu'nu oluşturan fayları çoğunlukla dik keserler. Bu durum, drenaj sisteminin gelişiminde ve havzaların jeomorfometrik özellikleri üzerinde etkili olmuştur. Sahada tektonik etkinliğin jeomorfometrik parametrelere yansıması ölçüsünde havzaların tektonik aktivite düzeyleri elde edilmiştir. Bu maksatla çalışma alanında seçilen 18 akarsu Rölatif Tektonik Aktivite İndeksi (IRAT) oluşturulmuştur. Çalışılan saha içerisinde Kös Dağı gibi litolojik bakımdan daha homojen olan kesimler yanında, Ilgaz Dağları gibi daha çeşitli kayaçlar sunan kesimlerin varlığı jemorfometrik parametreleri etkileyen unsurlar olmuştur. Bununla birlikte KAF Zonu'nu güneyden verev kesen, sağ yanal doğrultu atım bileşenli verev atımlı normal faylardan oluşan, Dodurga-Hacıhamza Fay Zonu'nun etkisi de bu parametrelere yansımıştır. Sahadaki litolojik ve tektonik değişkenliğe bağlı olarak göreli tektonik etki düzeyinin kısa mesafede farklılık gösterdiği anlaşılmaktadır. Elde edilen jemorfometrik parametrelerden genel olarak KAF'ın güney blokunda, özellikle Kös Dağı üzerinde yer alan akarsu havzalarında göreli tektonik aktivite düzeyinin daha yüksek olduğu anlaşılmaktadır.
\end{abstract}

Anahtar kelimeler: Rölatif tektonik aktivite indeksi, Jeomorfometrik analiz, Kuzey Anadolu Fay Zonu

\section{ABSTRACT}

The east-west Kızılırmak River Valley rests on a fault line in the central part of the North Anatolian Fault (NAF) Zone that extends from Tosya to Kargı from southwest to northeast, between the Devrez River Valley and Kargı-Kamil. The side creeks connected to the main streams from the slopes in both segments cut the faults that make up the NAF Zone, mostly steeply. This reflects in the drainage system and basin morphometry. Tectonic activity levels of the stream basins were obtained by measurement of the reflection of relative tectonic activity on geomorphometric parameters in the field. In addition to lithologically homogeneous segments such as Mount Kös, segments with more complex lithology, such as the llgaz Mountains, have been factors affecting geomorphometric parameters. The effect of the Dodurga-Hacıhamza Fault Zone, which cuts the NAF Zone in the south and consists of normal faults with right-lateral displacement, is reflected in these parameters. The geomorphometric parameters obtained in the southern block of the NAF, especially in the stream basins on Mount Kös, indicate that relative tectonic activity is higher there.

Keywords: Relative Tectonic Activity Index, Geomorphometric analysis, North Anatolian Fault Zone

Başvuru/Submitted: 05.01.2021 • Revizyon Talebi/Revision Requested: 11.05.2021 • Son Revizyon/Last Revision Received: 22.05 .2021 • Kabul/Accepted: $26.05 .2021 \cdot$ Online Yayın/Published Online: 25.06 .2021

Sorumlu yazar/Corresponding author: Mustafa ARIKAN / arikan.must@gmail.com

Atıf/Citation: Arikan, M., \& Ertek, T. A. Kuzey Anadolu Fay Zonu'nun Tosya-Kargı-Kamil arasındaki kesiminde akarsu havzalarının rölatif tektonik aktivite düzeylerinin jeomorfometrik yöntemlerle belirlenmesi. Cografya Dergisi, 42, 211-228. https://doi.org/10.26650/JGEOG2021-854016 


\section{EXTENDED ABSTRACT}

The trough-shaped Karg1 Depression in the central part of the North Anatolian Fault (NAF) Zone is a pull-apart basin that developed among strike-slip fault zones from Tosya on the west to Kamil on the east. From the mountainous masses in the north and south block of NAF, stream basins that are ingrown into this tectonic groove have developed. Devrez River and Kizllırmak River are the main streams settled in the groove. The oldest stream sediments belonging to the fluvial system, which was established in parallel with the development of the NAF Zone in the field, are made up of the canal and flood plain sediments belonging to the Pliocene. The other members of the section are basic Triassic-Jurassic metamorphites, Cretaceous ophiolites, and flysch-type sediments of the Upper Cretaceous. Neogene stream sediments located on the valley slopes near the bases of the Ilgaz and Saraycik mountains in the northern block of the NAF are not found on Mount Ada and Mount Kös in the southern block. However, Quaternary alluvium is found on the Triassic-Jurassic metamorphites of Mount Kös in the southern block. Reaching for about $60 \mathrm{~km}$ on the Tosya-Karg1-Kamil fault line, these creeks connected to the main streams in this tectonic groove are mostly reflected in the tectonic effect, drainage system, and basin morphometry as they cut the right-lateral strike-slip faults that make up the NAF Zone upright. Depending on the tectonic development and movement characteristics of the NAF, there are secondary fault lines parallel to the main fault, drainage system that matches the reach of the fault, fault valleys, side by side of different lithological elements, streams removed due to faults, displaced ridges, grabbings, pressure ridges, travertine formations, tectonic landslides, side-by-side alluvial fans, and displaced alluvial fans.

It is intended to determine the levels of tectonic activity affecting the shaping of stream basins in the measure of reflection of tectonic activity on morphometric parameters in the field. Therefore, a relative tectonic activity index was created for 18 drainage basins in the study area. Advanced Land Observing Satellite (ALOS) digital elevation model (DEM) data with a resolution of $30 \mathrm{~m}$ was used to calculate these indexes.

The main factors affecting the formation of the relative tectonic activity levels expressed by the geomorphometric indices of the study area; these are the tectonic movements of the North Anatolian Fault Zone and the Dodurga-Hachamza Fault Zone. In general, tectonic effects are more pronounced in the morphometric parameters of basins located in the southern block of the NAF, whereas they are less obvious in the basins of the Ilgaz Mountains and Mount Sarayc1k in the northern block. In addition to lithologically homogeneous segments, such as Mount Kös, segments with more complex lithologies, such as the Ilgaz Mountains, have been factors affecting morphology. The effect of lithology is evident in shaping the surface, especially in the Ilgaz Mountains basins.

According to the Relative Tectonic Activity Index obtained by taking the average of tectonic activity levels expressed by all geomorphometric index values applied in the field, high or very high tectonic activity level was achieved in 12 of the 18 basins in the study area and moderate activity level in 4 basins and weak activity level in 2 basins. The area with the highest level of tectonic activity is on Mount Kös, where the only basin in the very high relative tectonic activity class, the Eminlik Creek Basin, is found. As stated in other analyses, this phenomenon is an effect of the Dodurga-Hacıhamza Fault Zone, which is comprised of oblique faults and limits Mount Kös on the east. However, two basins located within the NAF Zone are in the low relative tectonic activity class, the Avlu Creek Basin near Tosya and the Süpürgelik Creek Basin near Kamil. In these basins, morphometric parameters representing mature fluvial systems were obtained. As a matter of fact, there are sedimentological elements between Karg1 and Tosya that signal the presence of an early (Neogene) drainage system.

The relationship of the rivers valleys of Devrez and Kizılırmak, sedimantological elements with faults, the direction of paleo-current and valley morphometry on the Tosya-Karg1-Kamil line; Here, it is understood that the first bed was built on the masses of Ilgaz and Saraycik, further north than today, and over time it migrated south to the foothills of Mount Kös, Ada Mountain, and thus the tectonic trough took on the appearance of an asymmetric valley. 


\section{GÍRIŞ}

Kuzey Anadolu Fay (KAF) Zonu, Doğu Anadolu'da sıkışmalı ve Batı Anadolu'da genişlemeli tektonik rejime sahip iki fay sistemi arasında gerilme aktarımı sağlayan sağ yanal doğrultu atımlı bir kıta içi fayı olup Anadolu'nun batı-güneybatıya kaymasını sağlamaktadır (McKenzie, 1972; Şengör, 1985; Dewey vd., 1986; Över, 1999; Özalp vd., 2013). Jeomorfolojik açıdan KAF Zonu aynı zamanda Anadolu'nun kuzeyi boyunca yüzey deformasyonuna neden olmuş ve doğrultu atımlı faylara özgü yerşekillerinin ortaya çıkmasını sağlamıştır. Çalışma alanı KAF Zonu'nun orta kesiminde, doğrultu atımlı fay zonları boyunca gelişen çek-ayır havza özelliğindeki (Tüysüz, 2017) Kargı Depresyonu ve yakın çevresini kapsamaktadır. KAF Zonu içinde açılan, Kızılırmak'ın ve Devrez Çayı'nın içine kanalize olduğu Tosya-Karg1-Kamil hattında uzanan bu tektonik oluk içerisinde akaçlanan birçok küçük alanlı akarsu havzası gelişmiştir.

Tektonik hareketlerin yeryüzünde meydana getirdiği deformasyonun jeomorfometrik indislerle değerlendirilmesine olanak sağlayan çeşitli yöntemler geliştirilmiştir (Hack 1973; Bull ve Mc Fadden, 1977; Lepold ve Wolman, 1977; Keller ve Pinter, 1996; 2002; Elhamdouni vd., 2008). Topografyanın ve drenaj sisteminin tektonik süreçlere verdiği tepkilerin ölçülmesinde kullanışlı olan ve son dönemlerde sıklıkla kullanılmaya başlanan bu yöntemler çalışma alanına uygulanarak drenaj havzalarının göreli tektonik aktivite düzeylerinin belirlenmesi amaçlanmıştır.
KAF Zonu'nun Tosya-Kargi-Kamil arasındaki kesiminin gelişimini tektonik, litolojik, paleocoğrafik ve jeomorfolojik yönden inceleyen birçok çalışma bulunmaktadır (Akkan, 1977; Akkuş, 1980; Tüysüz 1985; Tüysüz ve Erturaç, 2005; Arıkan, 2020).

\section{1. Çalışma Alanının Lokasyonu ve Genel Özellikleri}

Çalışma alanı Orta Pontidler'de, Kuzey Anadolu Fay Zonu'nun Tosya-Kargi-Kamil arasındaki kesiminde yer alır (Şekil 1). Burada litolojik, tektonik ve jeomorfolojik yönden farklılık gösteren iki saha dikkati çeker. Bunlardan ilki, TosyaKargı arasında fay kontrolündeki tektonik oluk olup, Devrez Çayı bu olukta faylara paralel olarak GB-KD uzanımlı bir vadi içine yerleşmiştir. Burası aynı zamanda fay kontrolünde kurulmuş flüvyal sistemin kalın çökelleri ile doldurulmuştur. Sahanın kuzeyinde, Ilgaz Dağları'ndan güneye akaçlanarak Devrez Çayı'na bağlanan dereler ile güneyinde Kös Dağı'ndan kuzeye akaçlanarak Devrez Çayı'na bağlanan derelerin havzaları yer almaktadır. İkincisi ise Kargı-Kamil arasında yaklaşık B-D uzanımlı faylara paralel olarak kurulmuş Kızılırmak Vadisi’dir. Kizilırmak'ın Osmancık'tan Karg1 Depresyonu'na kadar, Dodurga-Hacıhamza Fay Zonu'nun kontrolünde, GD-KB istikametinde gelişen vadisi Devrez Çayı kavşağından sonra D-B istikametini alır. Bu çalışmada Kızılırmak'ın Osmancık Karg1 (Hacıhamza) arasındaki gidiş istikametinden saparak KAF Zonu'nda Devrez Çayı Vadisi'nin genel istikametine uyması Devrez Çayı'nın Kızılırmak'ı kapması olarak değerlendirilmiştir (Foto 1). Karg1 doğusunda, Kamil'e doğru Kızılırmak Vadisi, batısındaki Devrez Çayı Vadisi’ne göre daralır. Aynı zamanda vadinin göreli derinliği de artar.

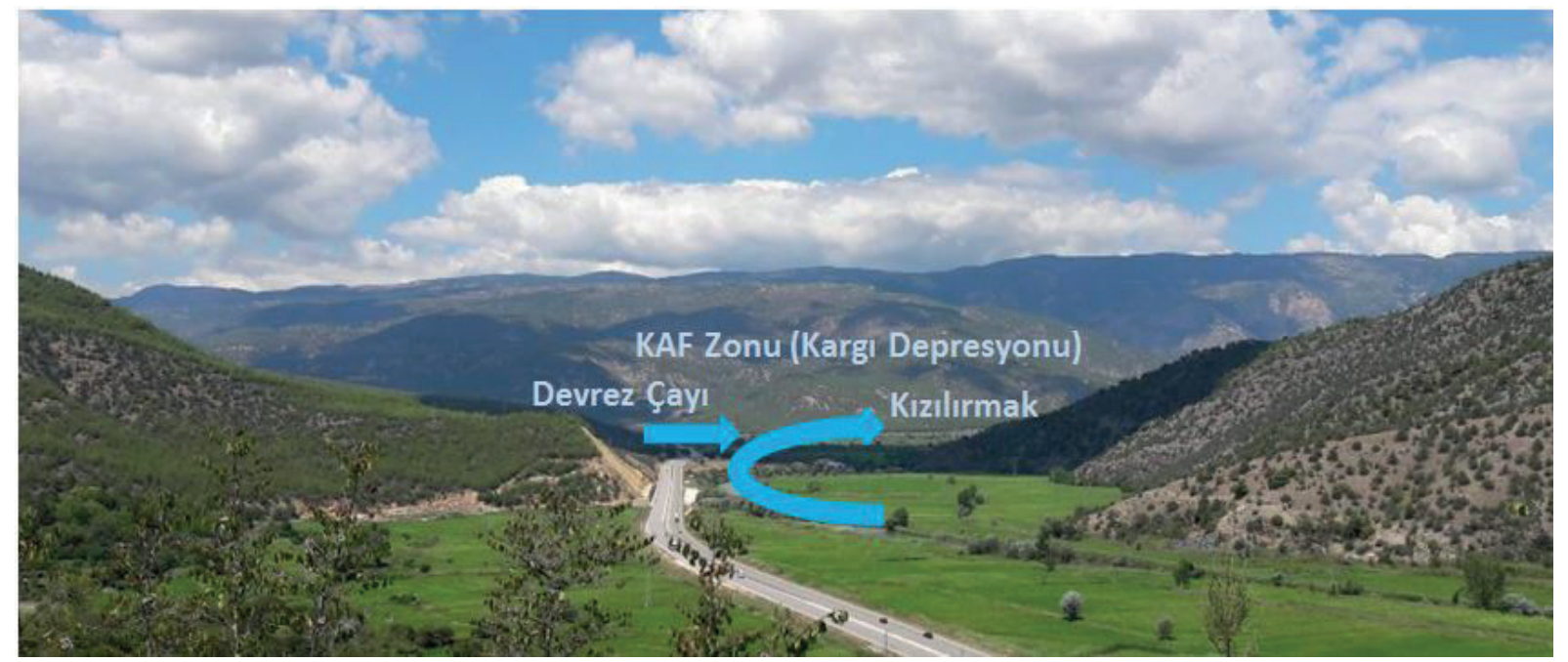

Foto 1: Kargı Depresyonu'nda Kızılırmak'ın Devrez-Kızılırmak oluğuna girişi (Bu kavşakta Kızılırmak Devrez Çayı'na kapılmıştır).

Photo 1: The entrance of Kızılırmak into Devrez and Kızılırmak trough during the Kargı Depression (At this intersection, it is connected to Kızılırmak to the Devrez River). 


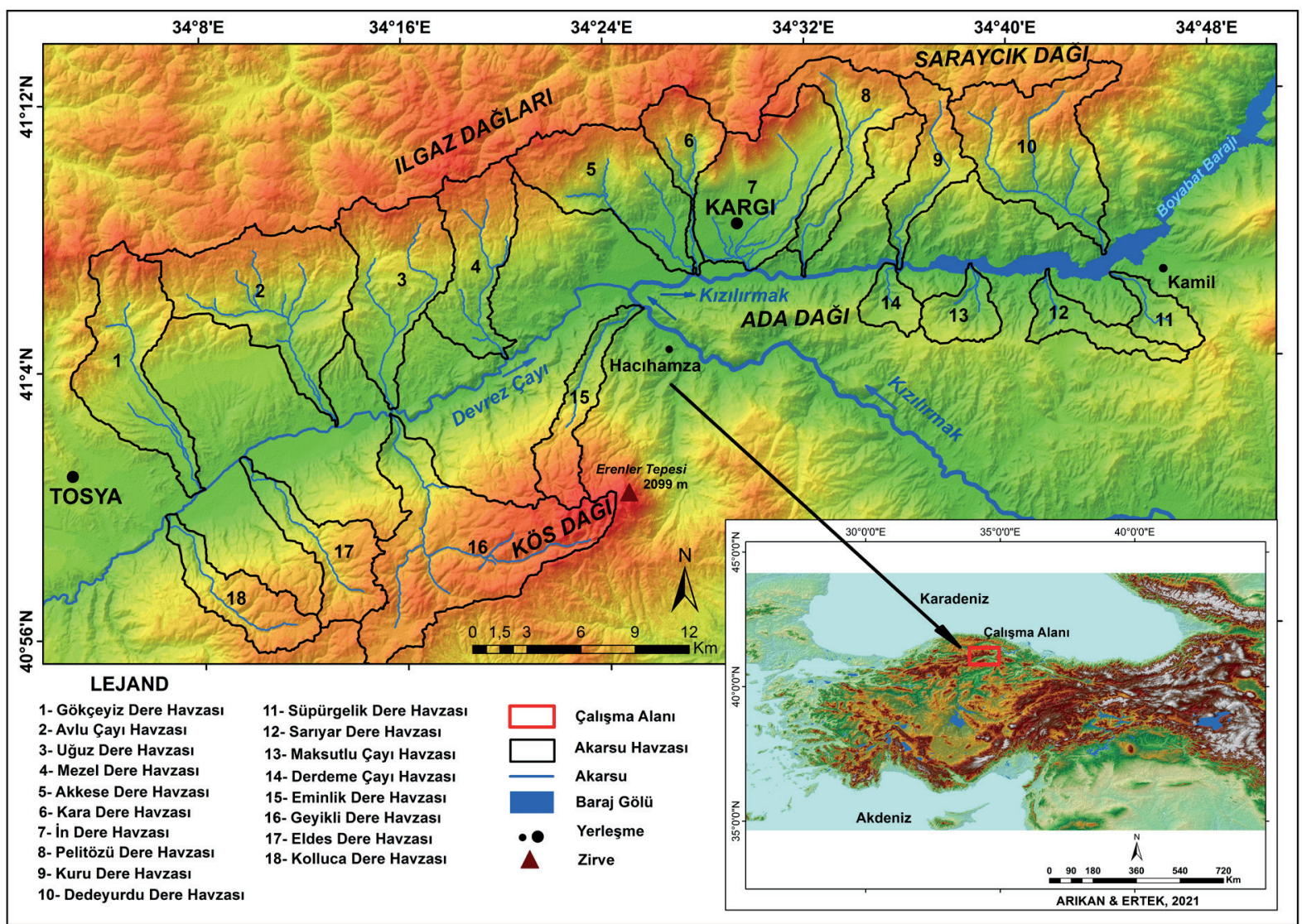

Şekil 1: Kuzey Anadolu Fay Zonu'nun Tosya-Kargı-Kamil arasındaki kesiminde alt akarsu havzalarının haritası.

Figure 1: Map of the creek basins in the North Anatolian Fault Zone along Tosya-Kargı and Kamil line.

Karg1 doğusunda litolojik olarak da önemli farklılıklar dikkati çeker. Karg1-Tosya arasında geniş alanlarda yüzeylenen Pliyosen'in akarsu çökellerine Kargı doğusunda daha sınırlı alanlarda rastlanır. Bu alüvyonlar Kargı doğusunda güncel nehir yatağına uzak ve yalnızca kuzey yamaçta yüzeylenir. Devrez Çayı Vadisi'nde rastlanan ve taraçalar meydana getiren Pleyistosen akarsu çökellerine ise Kargı doğusunda dar bir alan haricinde rastlanmaz.

Sahanın temelinde Permiyen ve Triyas-Jura metamorfitleri ile Geç Kretase ofiyolitleri yer alır. Metamorfik unsurlar, Triyas başında açılan ve Alt Jura öncesinde kapanan (Ketin, 1983; Şengör ve Yılmaz, 1981; Tüysüz ve Yiğitbaş, 1994), Karakaya iç denizinin ürünüdür. Ofiyolitler ise Mesozoik'te Neotetis'in kuzey kolunun Sakarya Kitası altında tüketilmesi sürecinde oluşmuştur. $\mathrm{Bu}$ ofiyolitler Erken Tersiyer'de aşırı sıkışma nedeniyle Lütesiyen öncesi temel üzerine retro-şariye olmuştur (Şengör ve Yılmaz, 1981, Yılmaz ve Tüysüz, 1984).

Kargı Masifi ve çevresi Neotetis Okyanusu'nun kapanımı esnasındaki olaylardan şiddetli etkilenmiştir. Bölgenin Tersiyer tektoniği, bu okyanusal ortamın kapanmasını sağlayan ve sonra da devam eden kompresyonel rejim tarafından kontrol edilmiştir (Tüysüz ve Dellaloğlu, 1994). Neotetis'in kapanımı sonrasında bölgedeki tüm birimler üzerinde Eosen çökel ve volkanitlerinin gelişmiş olduğu ve Eosen sonrası ile Neojen arasındaki dönemde bölge aşınma alanı halinde kaldığı anlaşılmaktadır (Tüysüz ve Erturaç, 2005). Bölgeye Kuzey Anadolu Fayı'nın yerleşmesi ile birlikte fay kontrolünde gelişen akarsu havzalarının kanal ve taşkın ovası çökelleri oluşmaya başlamıştı. Tosya'dan Kargı doğusuna kadar uzanan Geç Pliyosen'in (Uğuz ve Sevin, 2009) bu birimleri ile Kuvaterner'in eski ve yeni alüvyonları çalışma alanının en genç litolojik unsurlarını meydana getirmektedir (Şekil 2).

\section{VERİ VE YÖNTEM}

\subsection{Hipsometrik İntegral ve Hipsometrik Eğri}

Hipsometrik eğri, belli bir sahanın yükseklik dağılımını ifade eder. Bu dağılım aynı zamanda sahanın yükseklik kademesi ile alan ilişkisini tanımlar. Hipsometrik integral değeri ise hipsometrik eğri grafiğinin altında kalan alanın oransal ifadesidir (Strahler 


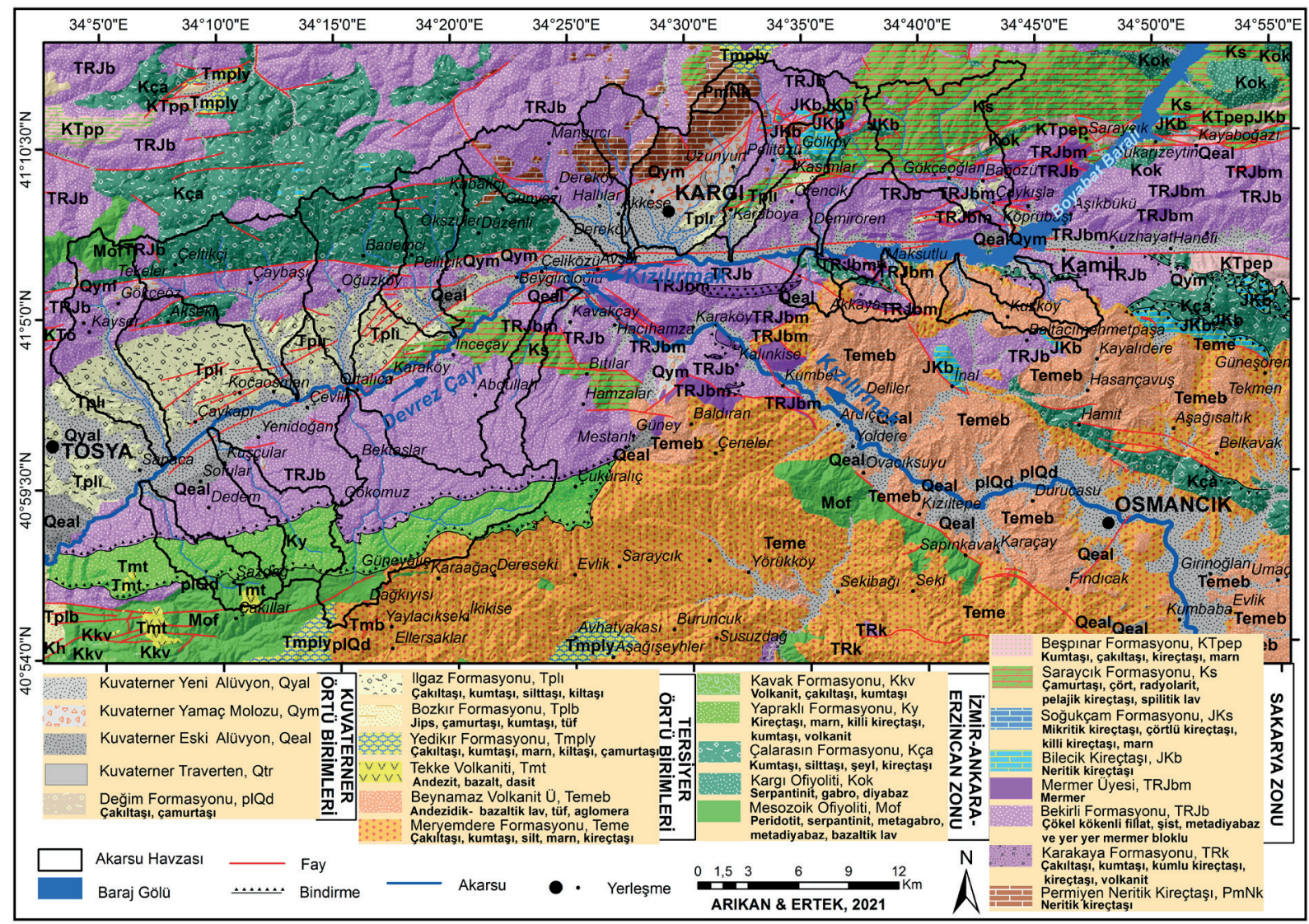

Şekil 2. Kuzey Anadolu Fay Zonu'nun Tosya-Kargı-Kamil arasındaki kesiminin litolojik ve tektonik haritası.

Figure 2. Lithological and tectonic map of the North Anatolian Fault Zone along Tosya-Kargı and Kamil line.

1952). Bir başka ifade ile yarılım öncesinde 1 olarak kabul edilen kütlenin yarılım sonrasında aşınımdan arta kalan güncel oranıdır. Hipsometrik integral değeri şu formülle ifade edilir.

$$
H I=\frac{H \operatorname{mean}-H \min }{H \max .-H \min }
$$

Hipsometrik İntegralin 0,5 'ten büyüklüğü Hipsometrik Eğrinin dışbükeyliğini ifade ederken, jeomorfolojik gelişim açısından aşınımda gençleşmeyi temsil eder ve aynı zamanda tektonik etkinliğin varlı̆̆ına işaret eder. Hipsometrik integralin 0,5 ten küçüklüğü Hipsometrik eğrinin içbükeyliğini ifade ederken, jeomorfolojik gelişim açısından aşınımda yaşlılık evresini temsil eder. Hipsometrik integralin 0,5'e yakın olması, Hipsometrik eğrinin doğrusallığını ifade ederken, jeomorfolojik gelişim açısından aşınımda olgunluk-yaşlılık evresini ve tektonik etkinliğin zayıf olduğunu işaret eder.

\subsection{Dağ Cephesi Sinüselliği (Smf)}

Dağ cephesindeki sinüziteyi ifade eden bu indis bir dağ 1 yarma eğiliminde olan erozyonal kuvvetler ile bu dağın önünü düz bir çizgisellikle sınırlandırma eğiliminde olan aktif fayların etki düzeyini ortaya koyar. Aktif tektonik etkinin yüksek olduğu alanlarda Smf değeri düşüktür. Bu alanlarda dağ cephesi nispeten daha düzdür. Aktif olmayan ya da düşük tektonik aktiviteye sahip alanlarda ise erozyonal süreçlerin ön plana çıkmasıyla Smf değeri yükselir ve dağ cephesi hattı çizgisellikten uzaklaşır (Keller ve Pinter 2002; Bull 2007). Smf oranı şu formülle ifade edilir.

$$
S m f=\frac{L m f}{L s}
$$

Smf, dağ cephesinin sinüsellik oranını, Lmf, dağ cephesindeki belirgin eğim kırıklığı boyunca uzanan hatta çizilecek eğrinin toplam uzunluğunu, Ls ise bu dağ cephesindeki hatta çizilecek doğrunun uzunluğunu ifade eder.

\subsection{Havza Şekil İndeksi (Bs İndex)}

$\mathrm{Bu}$ indis havza uzunluk oranını orta koyar. İndise göre bu oran havzanın en geniş yerindeki mesafenin kaynaktan ağıza olan uzunluğa oranıdır. Tektonik açıdan aktif ve gençleşen alanları karakterize eden uzamış şekilli havzalarda Bs indeks 
değeri yüksek, dairesel ve aktif olmayan havzalarda ise Bs indeks değeri düşüktür (Bull ve McFadden, 1977). Bs indeks şu formülle ifade edilir;

$$
B s=\frac{\mathrm{Bl}}{\mathrm{Bv}}
$$

Bl: Kaynaktan ağıza olan havza maksimum uzunluğunu, Bw: Havzanın maksimum genişliğini ifade eder.

Gençleşen havzalarda akarsuyun enerji artışına paralel olarak ağızdan su bölümü hattına doğru aşındırma gücü kazanacağından kapmalarla birlikte havza uzayacaktır. Buna karşın enerjisi azalan bir akarsuda yan dere etkinliği ön plana çıacak ve genişleme eğilimi gösteren havzalar daireselleşecektir.

\subsection{Havza Asimetrisi (AF)}

Zeminin tektonik etkiye maruz kalmadığ sahalarda akarsu, kararlı bir akışa sahip olup, drenaj havzasında ana akımın her iki tarafindaki alan yaklaşık bir birine eşit olur (AF 50). Buna karşın tektonik etki nedeniyle bir yöne eğimlenmiş havzalarda ana akım tepki olarak o yöne kayar. Akarsu drenajı ana akıma dik yönde meydana gelen eğim değişimlerine oldukça duyarlıdır (Keller ve Pinter, 2002). Bununla birlikte zeminde belli bir yönde meydana gelen yanal yer değiştirme hareketinin (blok rotasyonu) de havza asimetrisinde etkili olduğu ileri sürülmektedir (Yıldırım 2008; Yıldırım ve Tüysüz 2009). Buna görüşe göre homojen litolojik unsurlardan oluşan, ilksel eğime sahip havzalar ve akarsuyun aşındırma hızının blok rotasyonundan düşük olduğu havzaların simetrik, akarsuyun aşındırma hızının blok rotasyonundan büyük olduğu havzaların ise talveg hattının blok rotasyonunun tersi yöne kaydığı savunulmaktadır.

Asimetri Faktörü, drenaj havzasında ana akarsu hattının sağında kalan kesimin toplam drenaj alanına bölünmesi ile belirlenir. Havza asimetrisinin \%50'den farklılığ 1 oranında, havzada tektonik etkinliğin varlığı kabul edilir. Asimetri faktörü şu formülle elde edilir;

$$
\mathrm{AF}=\frac{A r}{A t}
$$

Formülde sAr akış istikametinin sağındaki alanı $\left(\mathrm{km}^{2}\right)$ ve At toplam havza alanı $\left(\mathrm{km}^{2}\right)^{\prime} \mathrm{n} 1$ ifade eder.

\subsection{Vadi Tabanı Genişliği - Vadi Yamaç Yüksekliği Oranı (Vf İndex)}

Bull ve Mcfadden (1977) tarafından geliştirilen bu indis vadi yamaçlarında aktif tektonizmanın etkisinin ortaya konulmasında kullanılmaktadır. İndis hesaplanırken çalışılan parametreler her vadi için dağ cephesinden belli bir mesafede ölçülür (Keller ve Pinter, 2002) Vadi tabanı genişliği-vadi yüksekliği oranı özellikle genç Kuvaterner tektoniğine karş1 hassas bir indistir. Çünkü genç tektonik hareketlerde kaide seviyesinin düşmesi ve kazılmanın hız kazanması vadi tabanının daralmasına neden olur. Bu durumda yüksek Vf değerleri aktif olmayan durumu ifade ederken, düşük $\mathrm{Vf}$ değerleri aktif tektonizmayı işaret eder (Bull, 2007). İndis şu formülle hesaplanır;

$$
V f=\frac{2 V f w}{[(E l d-E s c)+(E r d-E s c)]}
$$

Vfw: Vadi tabanın genişliğini, Eld: Sol vadi yamacının yüksekliğini, Erd: Sağ vadi yamacının yüksekliğini, Esc: Vadi tabanın deniz seviyesinden yüksekliğini ifade eder.

\subsection{Akarsu Uzunluk - Gradyan İndeksi (SL İndex)}

Akarsu Uzunluğu-Gradyan İndeksi, bir akarsu boyunaprofili üzerindeki eğim kırığının belirlenmesinde çok kullanışlıdır (Hack, 1973; Keller ve Pinter, 2002; Bull, 2007). Bu eğim kırıklığı çoğu kez akarsu yatağındaki litolojik unsurların değişkenliği ve tektonik etkinliklerle açıklanabilir. Daha az olmakla birlikte eğim kırıklğı, heyelanlarla, moloz akmalarıyla, bazen de beşeri faaliyetler ve yapılarla ilgili olabilir. SL indeks şu formülle ifade edilir:

$$
\text { SL İndeks }=\frac{\Delta \mathrm{H}}{\Delta \mathrm{L}} * \mathrm{~L}
$$

$\Delta \mathrm{L}$ : indisi hesaplanan akarsu uzunluğunu, $\Delta \mathrm{H}$ : indisi hesaplanan akarsu üzerindeki noktaların yükselti artışını, L: indisi hesaplanan noktanın akarsuyun kaynak noktasına olan uzaklığını ifade eder.

\subsection{Rölatif Tektonik Aktivite İndeksi (Irat)}

Jeomorfolojik durumun aktif tektonikle ilişkisini ortaya koymaya yarayan kullanışlı bir indis El Hamdouni vd. (2008) tarafindan geliştirilmiştir. $\mathrm{Bu}$ indis 6 farklı jeomorfometrik indisten elde edilen tektonik aktivite derecelerinin ortalamasının yeniden sınıflandırılması esasına dayanır. Rölatif Tektonik Aktivite Sinıflaması'nda kullanılan indisler; Hipsometrik İntegral (HI), Dağ Cephesi Sinüzitesi (Smf), Drenaj Havzası Şekil İndeksi (Bs), Drenaj Havzası Asimetri Faktörü (AF), Vadi Tabanı Genişliğinin Vadi Tabanı Yüksekliğine Oranı (Vf) ve Akarsu Uzunluk-Gradyan İndeksi (SL)'dir. Bu sinıflamaya göre; IRAT $<1,5$ (Çok yüksek aktivite), IRAT= 1,5-2,0 (Yüksek aktivite), IRAT=2,0-2,5 (Orta düzey aktivite) IRAT $>2,5$ (Zayıf aktivite veya aktif olmayan). 


\section{BULGULAR VE TARTIŞMA}

Tektonik aktivite, sahada drenaj sisteminin gelişimini, flüvyal sistemin aşınım ve birikim faaliyetlerini kontrol eden en önemli etkendir. KAF'ın Tosya-Karg1-Kamil arasındaki orta kesimini oluşturan ve doğrultu atım tektoniğinin önemli morfolojik unsurlarını sunan saha aynı zamanda Kuzey Anadolu Fayı'nın Orta Pontidler'de büklüm yaptığı kesimdir. Doğrultu atımlı fay sistemlerinde fayların sıçrama ve büküntülerinde gelişen çek-ayır havza özelliği gösteren Kargı çevresi (Tüysüz, 2017) genç alüvyonlar tarafindan doldurulmuş, tektonik ve flüvyal süreçlerin kontrolünde ova görünümü almıştır. Sahada Kuzey Anadolu Fayı'nın tektonik gelişim ve hareket özelliklerine bağlı olarak ana faya paralel tali fay çizgiselliklerine, fayın uzanışına uyan drenaj sistemine, fay vadilerine, farklı litolojik unsurların yan yana gelmesine, faylanmalar nedeniyle ötelenmiş akarsulara, kapmalara, basınç sırtlarına, traverten oluşumlarına, tektonik kökenli heyelanlara, yan yana sıralanmış alüvyon yelpazelerine ve ötelenmiş yelpazelere sıkça rastlanılmaktadır (Foto 2).

Flüvyal sistemin aşındırıcı etkisini denetleyen bir başka unsur litolojidir. Kayaçların aşınmaya karşı mukavemetleri farklılık göstermektedir. Selby (1980) tarafindan kayaç türlerinin jeomorfolojik süreçlerdeki mukavemetlerinin sinıflandırıldığ çalışmada kayaçlar, düşük, orta ve yüksek dayanımlı olarak ayırt edilmiştir. Bu sınıflamaya göre çalışma alanının büyük bir kısmı yüksek dayanımlı metamorfik kayaçlardan meydana gelmektedir.
Bununla birlikte Tosya-Kargı arasında Devrez Çayı Vadisi'nin tabanı ve tabana yakın kuzey yamaçları düşük dayanımlı alüvyonlardan meydana gelirken subölümü hattı çevresi orta dayanımlı kırıntılı kayaçlardan meydana gelmektedir. Güney yamaçları oluşturan Kös Dağı kütlesi ise bu kesimde büyük oranda yüksek dayanımlı metamorfitlerden oluşmaktadır. Kızılırmak ve Devrez Çayı'nın kavşağındaki Kargı Depresyonu'nun tabanı ve tabana yakın kuzey yamaçları düşük dayanımlı alüvyonlar ve yamaç molozlarından, daha yüksek yamaçlar ise orta dayanımlı karbonatlı kayaçlar ve yüksek dayanımlı metamorfik kayaçlardan meydana gelmektedir. Kargı doğusunda Kızılırmak Vadisi’nin kuzey yamaçlarını oluşturan Saraycık Dağı'nın alçak yamaçları yüksek dayanımlı metamorfik unsurlar ve düşük dayanımlı alüvyonlardan, subölümü hattına yakın yüksek yamaçlar ise orta dayanımlı karbonatlı kayaçlardan meydana gelmektedir (Foto 3). Kargı depresyonu ve doğusunda Kızılırmak vadi tabanının güney yamaçlarını oluşturan Ada Dăğ'nın batı kesimi yüksek dayanımlı metamorfik unsurlardan meydana gelmektedir.

Sahanın jeomorfometrik indislerinin ifade ettiği tektonik aktivite düzeylerinin oluşmasında Kuzey Anadolu Fay Sistemi'nin doğrultu atım tektoniği ile birlikte özellikle güney bloktaki Kös ve Ada Dağı kütleleri arasındaki sağ yanal doğrultu atım bileşenli verev atımlı normal faylardan oluşan DodurgaHacıhamza Fay Zonu'nun belirleyici unsur olduğu anlaşılmaktadır (Foto 4).

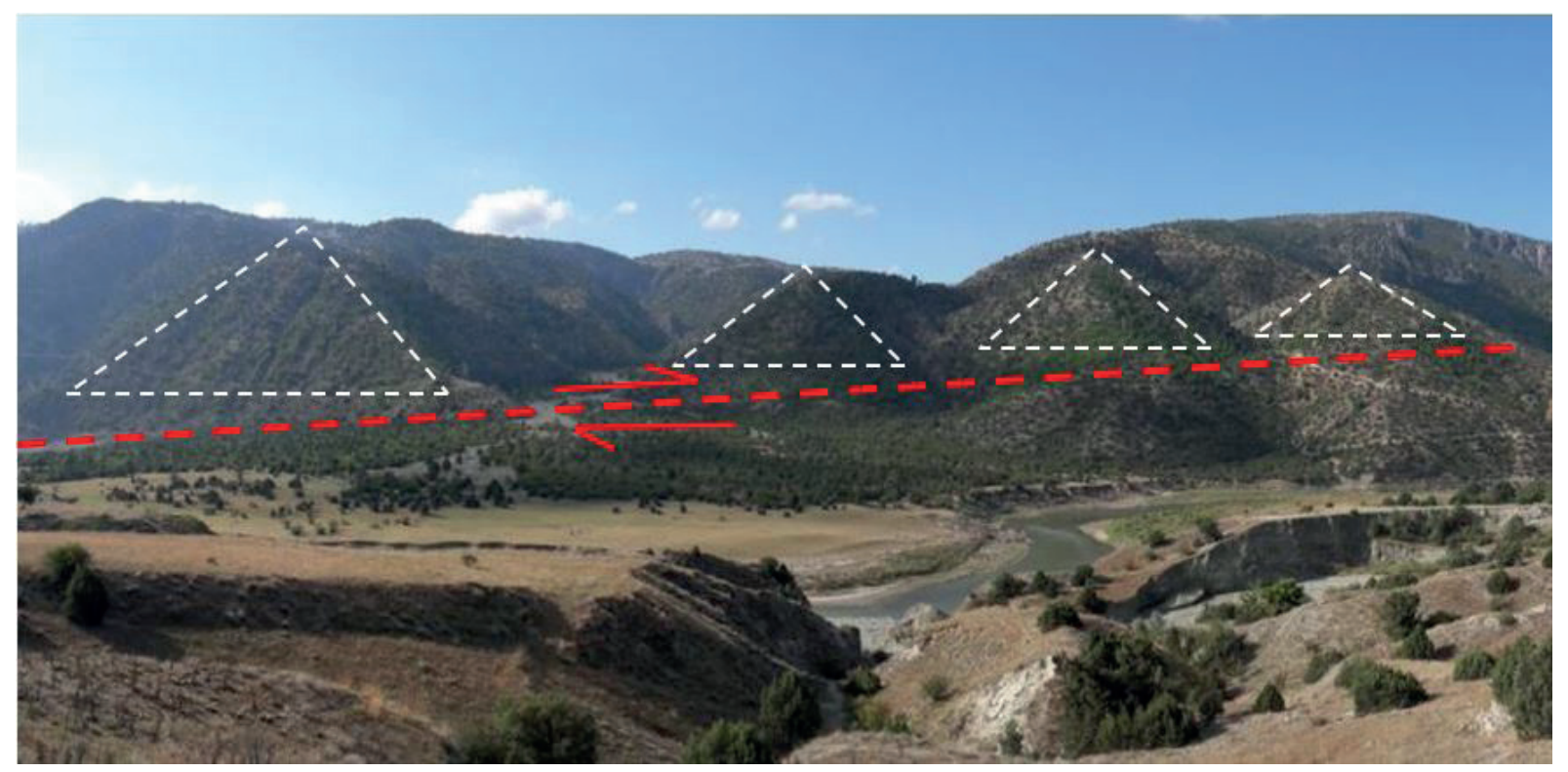

Foto 2: Fay façetaları, alüvyal yelpaze ve sırtlarda ötelenme (Demirören Köyü'nden güneye bakış). Photo 2: Fault facettas, alluvial fans and offset on ridges (looking south from to north Demirören Village). 


\subsection{Hipsometrik Eğri ve Hipsometrik İntegral}

Yarılım öncesinde 1 olarak kabul edilen kütlenin yarılım sonrasında aşınımdan arta kalan güncel oranını ifade eden hipsometrik integral değeri aynı zamanda yüzeyin sahip olduğu aşınım evresi ve tektonik aktivitesi hakkında fikir vericidir. KAF'ın kuzey blokunu oluşturan Ilgaz ve Saraycık Dağı kütlelerinden Devrez Çayı ve Kızılırmak'a ulaşan yan kollarda iki farklı kesimde dikkat çekici farklılıklar görülmektedir. Kargı batısında Gökçeyiz Dere, Uğuz Dere, Mezel Dere ve Akkese Dere havzalarında düşük hipsometrik integral değerlerine rastlanılmıştır. Kargı doğusunda ise Pelitözü Dere, Kuru Dere ve Dedeyurdu Dere havzalarında daha yüksek HI değerlerine rastlanılmıştır (Tablo 1).

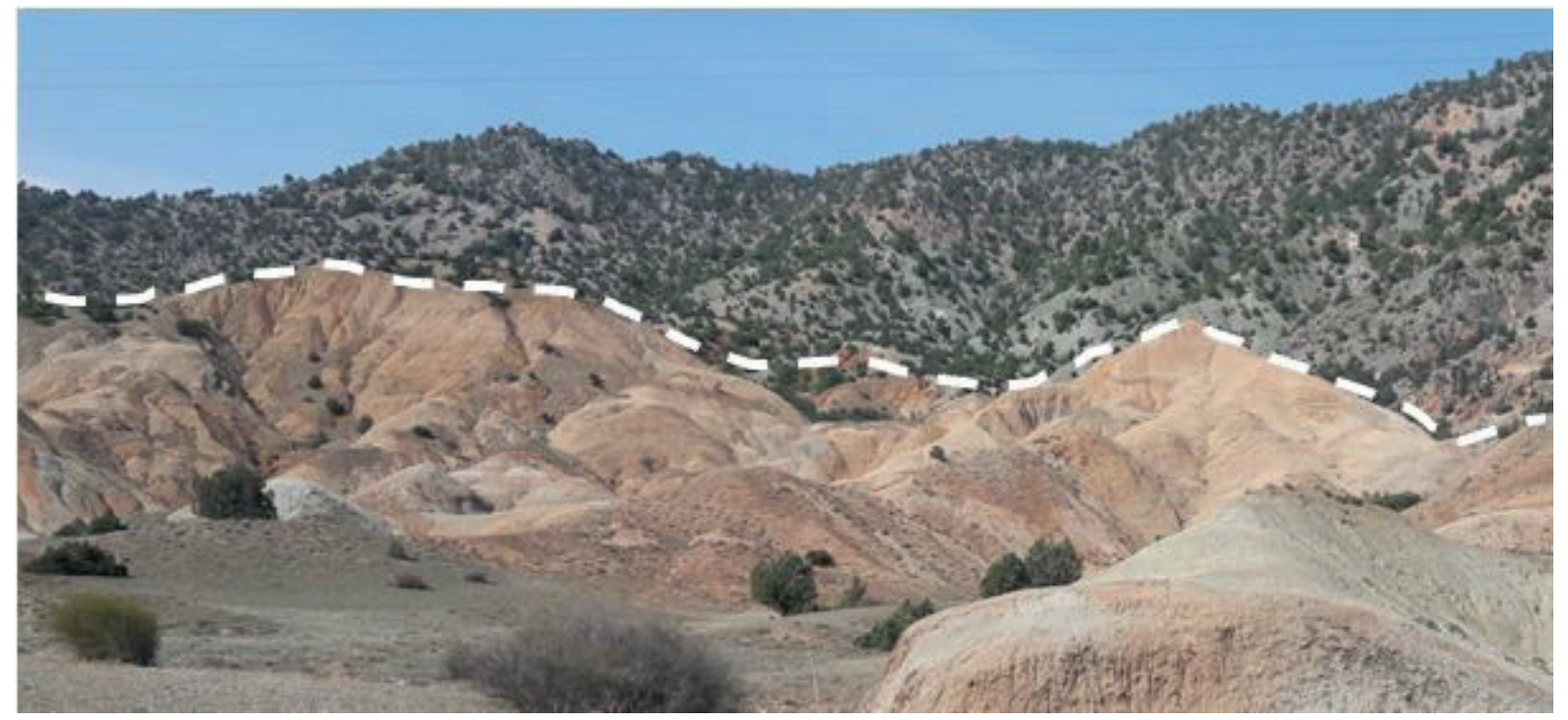

Foto 3: Köprübaşı Köyü batısında jeomorfometrik parametreler üzerinde etkili olan farklı dayanıma sahip kayaçların birlikteliği (önde Erken Pliyosen alüvyonları, arkada Triyas-Jura metamorfitleri,).

Photo 3: Coexistence of rocks with different strengths that affect geomorphometric parameters in the west of Köprübaşı Village the study area (Early Pliocene alluvium in front, Triassic-Jurassic metamorphics in the back).

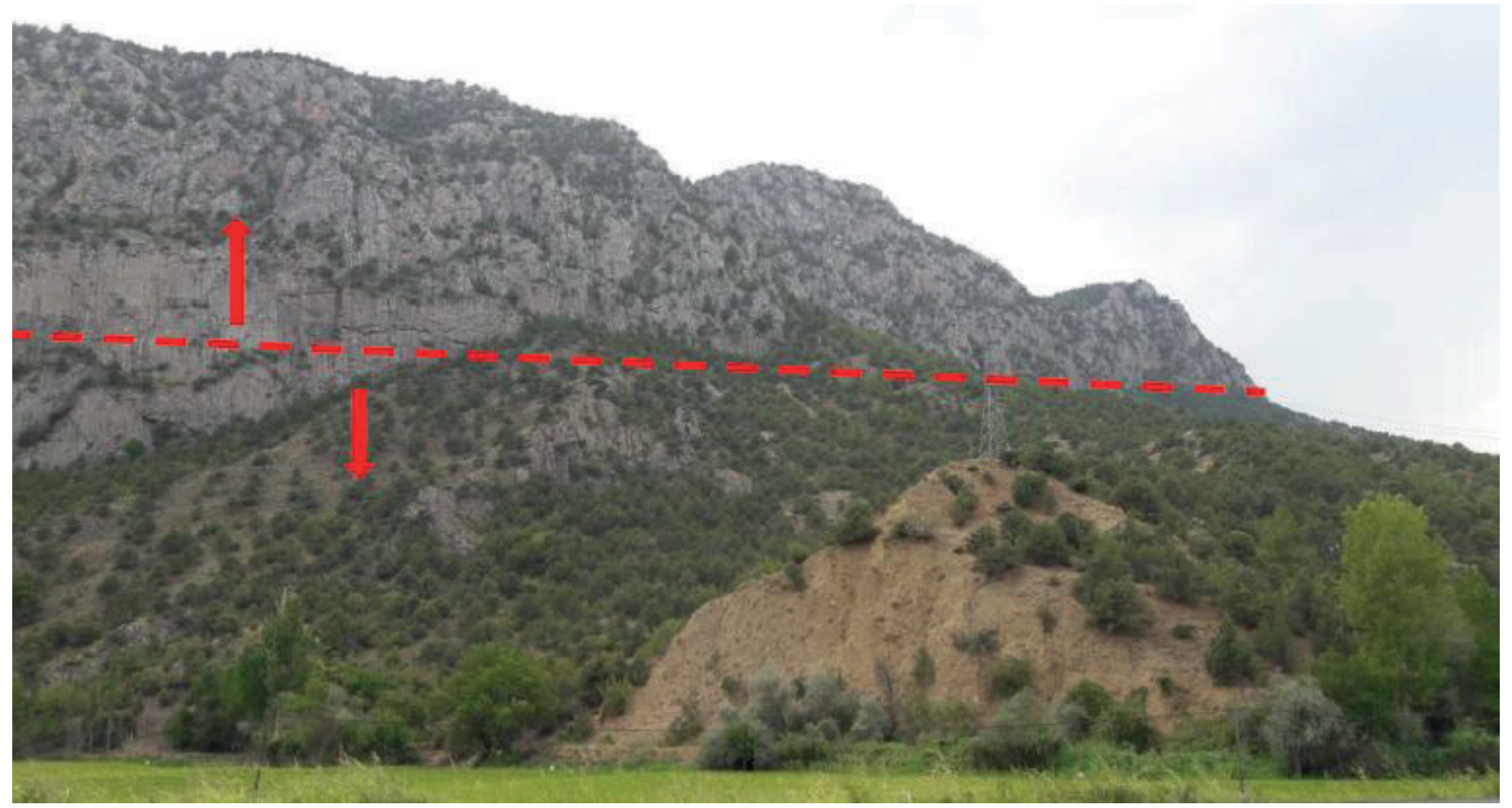

Foto 4: Kös Dağını doğudan sınırlandıran Dodurga-Hacıhamza Fay Zonu'nun oblik atımlı fayları ve oluşturduğu fay dikliği. Photo 4: The oblique faults and fault steepness created by Doduga-Hacıhamza Fault Zone, which limited Kös Mountain from the east. 
Tablo 1: Kuzey Anadolu Fay Zonu'nun Tosya-Kargı-Kamil arasındaki kesiminde akarsu havzalarının Hi değerleri, HE' leri ve bu değerlerinin ifade ettiği tektonik aktivite sınıfları.

Table 1: Hipsometric Integral values of river basins, Hipsometric Curves and tectonic activity classes created accordingly in the part of North Anatolian Fault Zone along Tosya-Kargı and Kamil.

\begin{tabular}{|c|c|c|c|c|}
\hline Havza No & Havza Adı & Hi & HE & Tek. Akt. Derecesi \\
\hline 1 & Gökçeyiz Dere Havzası & 0,44 & İçbükey & 2.Sinıf \\
\hline 2 & Avlu Çayı Havzası & 0,50 & Dışbükey & 1.Sinıf \\
\hline 3 & Uğuz Dere Havzası & 0,46 & İçbükey & 2.Sinif \\
\hline 4 & Mezel Dere Havzası & 0,47 & İçbükey & 2.Sinıf \\
\hline 5 & Akkese Dere Havzası & 0,45 & İçbükey & 2.Sinıf \\
\hline 6 & Kara Dere Havzası & 0,55 & Dışbükey & 1.Sınıf \\
\hline 7 & İn Dere Havzası & 0,33 & İçbükey & 3.Sinıf \\
\hline 8 & Pelitözü Dere Havzası & 0,53 & Dişbükey & 1.Sinıf \\
\hline 9 & Kuru Dere Havzası & 0,61 & Dışbükey & 1.Sınıf \\
\hline 10 & Dedeyurdu Dere Havzası & 0,59 & Dışbükey & 1.Sınıf \\
\hline 11 & Süpürgelik Dere Havzası & 0,46 & İçbükey & 2.Sinıf \\
\hline 12 & Sarıyar Dere Havzası & 0,45 & İçbükey & 2.Sinıf \\
\hline 13 & Maksutlu Çayı Havzası & 0,55 & Dışbükey & 1.Sınıf \\
\hline 14 & Derdeme Çayı Havzası & 0,56 & Dışbükey & 1.Sınıf \\
\hline 15 & Eminlik Dere Havzası & 0,54 & Dışbükey & 1.Sınıf \\
\hline 16 & Geyikli Dere Havzası & 0,68 & Dışbükey & 1.Sınıf \\
\hline 17 & Eldes Dere Havzası & 063 & Dışbükey & 1.Sınıf \\
\hline 18 & Kolluca Dere Havzası & 0,63 & Dışbükey & 1.Sınıf \\
\hline
\end{tabular}

Bu durum Kargı' dan Tosya'ya kadar olan batı kesimde büyük ölçüde Pliosen ve Kuvaterner alüvyonları ve Kretase flişleri gibi daha düşük dayanımlı litolojik unsurların varlığı ile ilgilidir. KAF'1n güney blokunda yer alan Ada Dağ1 ve Kös Dağ1 kütlelerinden Devrez Çayı ve Kızılırmak'a ulaşan alt havzalarda da benzer bir durum vardır. Batıda yüksek dayanımlı metamorfik unsurlardan oluşan Kös Dağı üzerindeki Eminlik Dere, Geyik Dere, Eldes Dere ve Kolluca Dere havzalarında oldukça yüksek Hİ değerlerine ulaşılmıştır (Şekil 3).

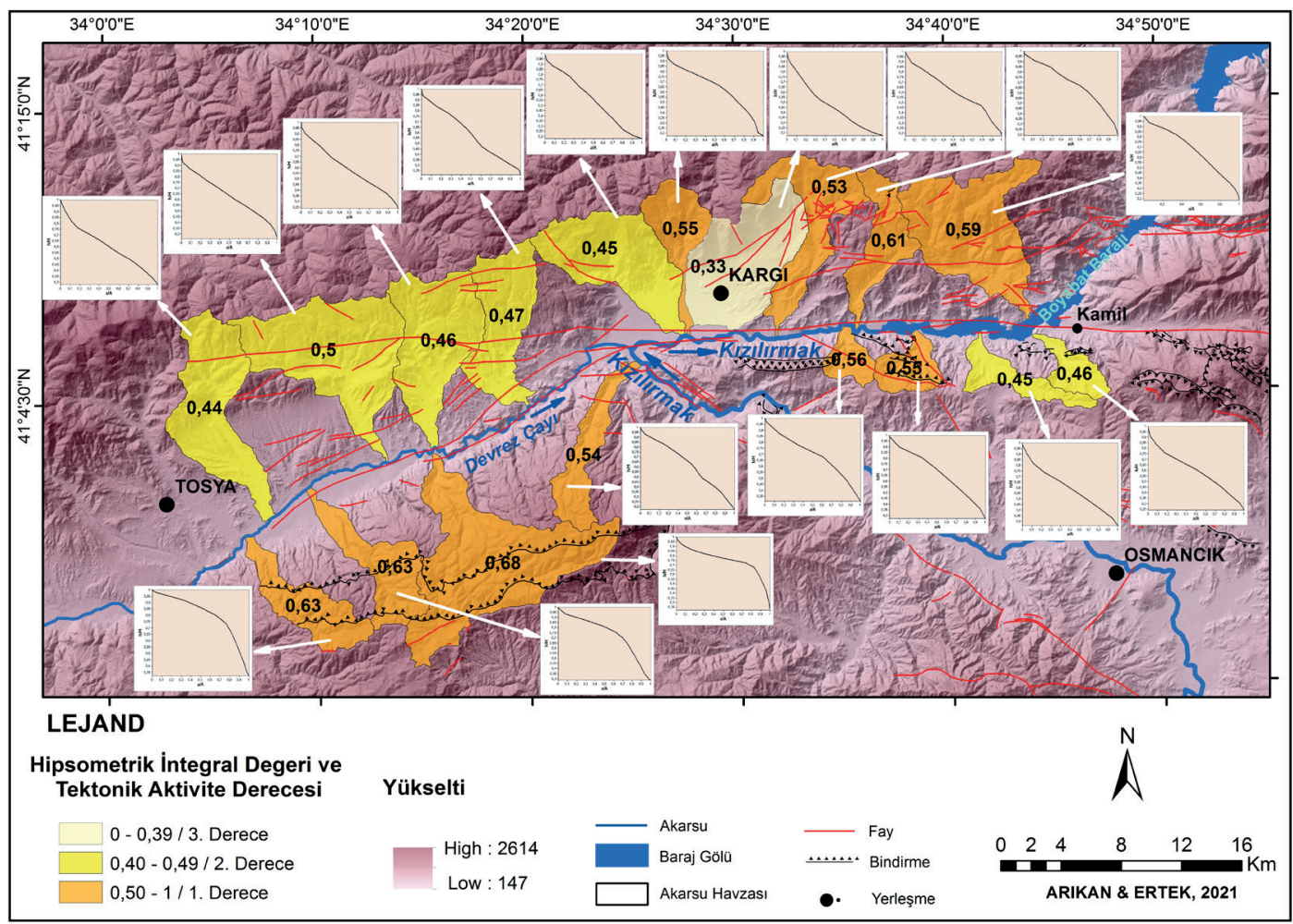

Şekil 3: Kuzey Anadolu Fay Zonu'nun Tosya-Kargı-Kamil arasındaki kesiminde akarsu havzalarının hipsometrik integral değerine göre oluşturulan tektonik aktivite sınıfları haritası.

Figure 3: Map of tectonic activity classes created according to hipsometric integral value of river basins in the part of North Anatolia Fault Zone along Tosya-Kargı and Kamil. 
Daha doğuda Ada Dağı'nın metamorfik unsurlardan oluşan zemini üzerinde kurulan Maksutlu ve Derdeme deresi havzalarının Hİ değerleri, doğuda yer alan, volkanit ve çeşitli kırıntılı kayaçlardan oluşan Süpürgelik Dere ve Sarıyar Dere havzalarına göre daha yüksek bulunmuştur. Ancak Kös Dağ1 üzerinde elde edilen diğer sahalara göre çok yüksek hipsometrik integral değerleri yalnızca litoloji ile açıklanamaz, bu durum Kös Dağı yükseliminde yüksek tektonik aktiviteyi işaret eder.

\subsection{Dağ Cephesi Sinüselliği}

KAF'ın kuzey ve güney bloğundaki dağlık kütlelerden Devrez Çayı ve Kızılırmak vadi tabanlarına uzanan alt havzaların tümünde, dağlık sahadan vadi tabanına geçişte dağın önünü çizgisellikle sınırlandırma eğiliminde olan aktif fayların etki düzeyini ortaya koymak maksadıyla Dağ Cephesi Sinüsellik Oranı hesaplanmıştır. Bunlardan 9'unda orta ve yüksek tektonik aktiviteyi işaret eden düşük dağ cephesi sinüsellik oranına, 9'unda ise düşük tektonik aktiviteyi işaret eden yüksek dağ cephesi sinüsellik oranına rastlanılmıştır (Tablo 2). Bazı dere ağızları çevresinde kuvvetli geriye ve yana aşınım nedeniyle düşük sinüzite değerleri ortaya çıkmıştır.

\subsection{Havza Şekil İndeksi}

Tektonik açıdan aktif ve gençleşen alanları karakterize eden uzamış şekilli havzalar ile dairesel ve aktif olmayan havzaların ayrımında kullanılan bu indise göre yüksek Bs değerleri (Bs > 4) gösteren 1. derece aktif ve orta düzeyde Bs değerine sahip (Bs = 3-4) orta derecede aktif havzalar sayıca azdır. Çalışma alanında yalnızca Kös Dağı doğusundan Kızılırmak'a akaçlanan Eminlik dere 1. Derece (yüksek) aktivite sınıfında yer almıştır. 2. derece aktivite sınıfında ise iki havza bulunmaktadır. Bunlardan birisi Kös Dă̆g'ndan Devrez Çayı'na akaçlanan Kolluca Dere, diğeri ise Tosya yakınlarında Ilgaz Dağları'ndan Devrez Çayı'na akaçlanan Gökçeyiz Dere havzalarıdır. Ancak Bs indeks değeri 1'den küçük olan havzalarda yapılan arazi gözlemlerinde kapma ile havzanın enine genişlediği ve daireselleştiği anlaşılmaktadır. $\mathrm{Bu}$ durum Bs indeks ile tektonik aktiviteyi açıklamada önerilen değerler dışında yeni bir eşik değerine ihtiyaç duyulduğunu göstermektedir. Bu havzalar dışında çalışma alanında yer alan diğer 15 havzada düşük tektonik aktiviteyi işaret eden Bs indeks değerlerine rastlanılmıştır (Tablo 3).

\subsection{Havza Asimetrisi AF}

Tektonik etkinliklerin havza asimetrisine neden olduğu bilinmektedir. Bununla birlikte asimetri litolojik kökenli de olabilmektedir. $\mathrm{Bu}$ nedenle indis litolojik bakımdan homojen sahalarda daha iyi sonuç vermektedir. El Hamduoni vd., (2008) bir drenaj havzasında $\mathrm{AF}$ oranının $\% 50$ den farklılığı oranında tektonik aktivitenin tesirinde olduğunu ileri sürmüşlerdir. Elhamdouni vd. (2008) Asimetri Faktörü oranlarının ifade ettiği 3 tektonik etkinlik sınıfı ayırt etmişlerdir. Bu sınıflamaya göre; [AF-50]>15 olmas1 durumunda saha 1. Derece tektonik

Tablo 2: Kuzey Anadolu Fay Zonu'nun Tosya-Kargı-Kamil arasındaki kesimindeki akarsu havzalarında ölçülen Dağ Cephesi Sinüsellik oranı ve buna göre sınıflandırılan tektonik aktivite düzeyleri.

Table 2: Mountain Front Sinusality rate measured in the river basins along Tosya-Kargı-Kamil of The North Anatolian Fault Zone and the tectonic activity levels classified accordingly.

\begin{tabular}{|c|c|c|c|c|c|}
\hline Havza No & Havza Adı & $\operatorname{Lmf}(m)$ & $\operatorname{Ls}(\mathbf{m})$ & Smf Oranı & Aktivite Derecesi \\
\hline 1 & Gökçeyiz Dere Havzası & 6582,45 & 5345,25 & 1,35 & Orta \\
\hline 2 & Avlu Çayı Havzası & 6044,76 & 4083,69 & 1,71 & Düşük \\
\hline 3 & Uğuz Dere Havzası & 7301,91 & 4467,88 & 1,48 & Orta \\
\hline 4 & Mezel Dere Havzası & 5752,39 & 3383,32 & 1,63 & Düşük \\
\hline 5 & Akkese Dere Havzası & 5202,97 & 4040,67 & 1,70 & Düşük \\
\hline 6 & Kara Dere Havzası & 5178,31 & 4764,38 & 1,29 & Orta \\
\hline 7 & İn Dere Havzası & 8368,47 & 3476,86 & 1,09 & Yüksek \\
\hline 8 & Pelitözü Dere Havzası & 6310,95 & 3058,10 & 2,41 & Düşük \\
\hline 9 & Kuru Dere Havzası & 4668,33 & 3029,76 & 2,06 & Düşük \\
\hline 10 & Dedeyurdu Dere Havzası & 4117,99 & 2890,01 & 1,54 & Düşük \\
\hline 11 & Süpürgelik Dere Havzası & 3513,92 & 2680,93 & 1,52 & Düşük \\
\hline 12 & Sarıyar Dere Havzası & 6053,73 & 4580,28 & 1,31 & Orta \\
\hline 13 & Maksutlu Çayı Havzası & 4872,30 & 3543,28 & 1,32 & Orta \\
\hline 14 & Derdeme Çayı Havzası & 3469,42 & 2881,23 & 1,38 & Orta \\
\hline 15 & Eminlik Dere Havzası & 3290,44 & 2589,94 & 1,48 & Orta \\
\hline 16 & Geyikli Dere Havzası & 5071,02 & 3061,04 & 1,27 & Orta \\
\hline 17 & Eldes Dere Havzası & 3725,56 & 2371,61 & 1,66 & Düşük \\
\hline 18 & Kolluca Dere Havzası & 2742,34 & 2030,69 & 1,57 & Düşük \\
\hline
\end{tabular}


Tablo 3: Kuzey Anadolu Fay Zonu'nun Tosya-Kargı-Kamil arasındaki kesiminde Havza Şekil İndeksi değerleri ve bu değerlere göre oluşturulan tektonik aktivite düzeyleri.

Table 3: Basin Shape Index values in the part of North Anatolia Fault Zone along Tosya-Kargı-Kamil and tectonic activity levels created according to these values.

\begin{tabular}{|c|c|c|c|c|c|}
\hline Havza No & Havza Adı & BI & Bw & Bs & Aktivite Derecesi \\
\hline 1 & Gökçeyiz Dere Havzası & 14687,38 & 4718,85 & 3,11 & Orta \\
\hline 2 & Avlu Çayı Havzası & 12104,63 & 10969,18 & 1,10 & Düşük \\
\hline 3 & Uğuz Dere Havzası & 11855,92 & 6176,95 & 1,91 & Düşük \\
\hline 4 & Mezel Dere Havzası & 11195,53 & 4611,01 & 2,42 & Düşük \\
\hline 5 & Akkese Dere Havzası & 11720,94 & 7877,73 & 1,48 & Düşük \\
\hline 6 & Kara Dere Havzası & 10559,28 & 4541,43 & 2,32 & Düşük \\
\hline 7 & İn Dere Havzası & 10853,24 & 6908,51 & 1,57 & Düşük \\
\hline 8 & Pelitözü Dere Havzası & 12288,99 & 8521,64 & 1,44 & Düşük \\
\hline 9 & Kuru Dere Havzası & 10977,11 & 3702,03 & 2,96 & Düşük \\
\hline 10 & Dedeyurdu Dere Havzası & 10909,98 & 9605,92 & 1,13 & Düşük \\
\hline 11 & Süpürgelik Dere Havzası & 6416,18 & 3160,63 & 2,03 & Düşük \\
\hline 12 & Sarıyar Dere Havzası & 9235,61 & 3747,24 & 2,46 & Düşük \\
\hline 13 & Maksutlu Çayı Havzası & 4344,60 & 4550,40 & 0,95 & Düşük \\
\hline 14 & Derdeme Çayı Havzası & 4180,84 & 3659,80 & 1,14 & Düşük \\
\hline 15 & Eminlik Dere Havzası & 11664,85 & 2807,75 & 4,15 & Yüksek \\
\hline 16 & Geyikli Dere Havzası & 12318,75 & 16901,00 & 0,72 & Düşük \\
\hline 17 & Eldes Dere Havzası & 11221,84 & 3845,61 & 2,91 & Düşük \\
\hline 18 & Kolluca Dere Havzası & 10651,52 & 3504,75 & 3,03 & Orta \\
\hline
\end{tabular}

aktiviteye, $[\mathrm{AF}-50]=7-15$ olmas1 durumunda 2. Derece tektonik aktiviteye, $[\mathrm{AF}-50]<7$ olması durumunda ise 3 . derece tektonik aktiviteye sahiptir. Çalışma alanında 18 havzanın 6 tanesinin 3 . Derece, 5'inin 2. Derece ve 7'sinin 1. Derece tektonik etkinlik sınıfında olduğu anlaşılmaktadır (Tablo 4). 1. Derece aktivite sınıfında olan 4 havza Tosya-Kargı arasında Ilgaz Dağları üzerindeki sahada, 1 tanesi Karg1 doğusunda Saraycık Dağ1 üzerindeki sahada, 2 tanesi ise Ada Dağı üzerindeki sahada yer alır. Kös Dağı üzerindeki havzalarda ise çoğunlukla 2. Derece tektonik aktiviteyi ifade eden AF oranları elde edilmiştir Ancak bunlardan litolojik homojenliğe sahip olması nedeniyle Kös Dağı üzerinde elde edilen değerlerin daha isabetli olduğu düşünülmektedir.

Tiltlenme yönleri açısından değerlendirildiğinde özellikle Kös Dağı üzerindeki talveg hattı kaymasının blok hareketinin yönü ile aynı olması dikkat çekicidir. Keller ve Pinter (2002) tektonik etki nedeniyle bir yöne eğimlenmiş havzalarda ana

Tablo 4: Kuzey Anadolu Fay Zonu'nun Tosya-Kargı-Kamil arasındaki kesiminde Havza Asimetrisi Oranı ve bu orana göre oluşturulmuş tektonik aktivite düzeyleri.

Table 4: Basin Asymmetry Ratio in the part of North Anatolian Fault Zone along Tosya-Kargı-Kamil and tectonic activity levels established according to this ratio.

\begin{tabular}{|c|c|c|c|c|c|c|c|}
\hline No & Havza Adı & Sağ Havza km² & Taplam Havza alanı & AF Oranı & 50-AF & Tiltlenme Yönü & Aktivite Sınıfı \\
\hline 1 & Gökçeyiz Dere Havzası & 32,47 & 46,09 & 70,46 & $-20,46$ & Sola & 1 derece \\
\hline 2 & Avlu Çayı Havzası & 28,53 & 61,97 & 46,04 & 3,96 & Sağa & 3 derece \\
\hline 3 & Uğuz Dere Havzası & 14,42 & 44,37 & 32,51 & 17,49 & Sağa & 1 derece \\
\hline 4 & Mezel Dere Havzası & 22,43 & 34,00 & 65,98 & $-15,98$ & Sola & 1 derece \\
\hline 5 & Akkese Dere Havzası & 22,51 & 43,77 & 51,43 & $-1,43$ & Sola & 3 derece \\
\hline 6 & Kara Dere Havzası & 9,78 & 18,37 & 53,26 & $-3,26$ & Sola & 3 derece \\
\hline 7 & İn Dere Havzası & 43,80 & 50,18 & 87,29 & $-37,29$ & Sola & 1 derece \\
\hline 8 & Pelitözü Dere Havzası & 14,53 & 32,99 & 44,05 & 5,95 & Sağa & 3 derece \\
\hline 9 & Kuru Dere Havzası & 12,97 & 21,11 & 61,46 & $-11,46$ & Sola & 2 derece \\
\hline 10 & Dedeyurdu Dere Havzası & 15,25 & 52,97 & 28,78 & 21,22 & Sağa & 1 derece \\
\hline 11 & Süpürgelik Dere Havzası & 4,52 & 9,97 & 45,43 & 4,57 & Sağa & 3 derece \\
\hline 12 & Sarıyar Dere Havzası & 3,45 & 13,32 & 25,95 & 24,05 & Sağa & 1 derece \\
\hline 13 & Maksutlu Çayı Havzası & 3,40 & 11,94 & 28,53 & 21,47 & Sağa & 1 derece \\
\hline 14 & Derdeme Çayı Havzası & 3,39 & 8,28 & 41,02 & 8,98 & Sağa & 2 derece \\
\hline 15 & Eminlik Dere Havzası & 12,18 & 19,75 & 61,67 & $-11,67$ & Sola & 2 derece \\
\hline 16 & Geyikli Dere Havzası & 47,71 & 79,50 & 60,02 & $-10,02$ & Sola & 2 derece \\
\hline 17 & Eldes Dere Havzası & 14,64 & 25,52 & 57,40 & $-7,40$ & Sola & 2 derece \\
\hline 18 & Kolluca Dere Havzası & 12,15 & 23,16 & 52,49 & $-2,49$ & Sola & 3 derece \\
\hline
\end{tabular}


akımın tepki olarak o yöne kaydığını ifade etmişlerdir. Elde edilen indis sonucuna göre Kös dağı kuzey yamaçları batıya eğimlenmiş ve tüm havzalarda ana akım talveg hattı batıya kaymıştır. Kös Dağı'nı doğudan sınırlandıran DodurgaHacıhamza Fay Zonu'nu oluşturan doğrultu atım bileşenli normal faylar boyunca sahanın yükselimi ile Kös Dağı kuzey yamaçlarının batıya eğimlendiği anlaşılmaktadır (Şekil 4).

Doğuda Ada Dağı üzerindeki tüm havzalarda ise tiltlenme yönleri blok hareketinin tersi yöne (doğuya) dir. Benzer şekilde Ada Dağı'nın kuzeye bakan yamaçları üzerindeki akarsu havzalarında da kütleyi batıdan sınırlandıran doğrultu atım bileşenli normal faylar boyunca yükselimi nedeniyle talveglerin doğuya kaydığı ve yüzeyin doğuya eğimlendiği anlaşılmaktadır. KAF'ın kuzey blokunda yer alan Ilgaz ve Saraycık dağlarındaki havzalarda ise tiltlenme yönleri düzensizdir. Kuzey kesim aynı zamanda litolojik açıdan da çeşitlilik arz eder. Bu bakımdan sahadaki drenaj havzası asimetrilerinde ve tiltlenme yönlerinde farklı etkilerin varlığı söz konusudur. Kuzey blokta yer alan havzalarda litolojik unsurların etkisi dikkati çekerken güney blokta Ada Dağı ve Kös Dağı kütlesi üzerinde ise verev atımlı faylardan oluşan Dodurdga-Hacıhamza Fay Zonu'nun daha belirgin etkiye sahip olduğu anlaşılmaktadır.

\subsection{Vf İndeks}

Sahadaki kazılma hızı ve aktif tektonik hareketlerin etkisi hakkında fikir veren bu indisten elde edilen sonuçlar Elhamdouni vd. (2008)'nin esas aldığı eşik değerlerine göre sınıflandırılmıştır. Buna göre $\mathrm{Vf}<0,51$. derece (yüksek aktivite) aktif sahaları, $\mathrm{Vf}=$ 0,5-1 arası 2. derece (orta düzey aktivite) aktif sahaları, $\mathrm{Vf}>1$ ise 3. derece aktif (düşük aktivite) sahaları işaret eder. Çalışma alanında 18 havzanın 3 farklı mecrasında yapılan 54 profilin 35 inde yüksek tektonik aktiviteyi işaret eden Vf indeks değerlerine rastlanılmıştır (Tablo 5). Az sayıda düşük aktiviteyi işaret eden değerler TosyaKargı arasında Ilgaz Dağları üzerindeki Gökçeyiz Dere, Avlu Çayı ve İn Dere havzalarında ortaya çıkmıştır. Çalışma alanında akarsu yatak eğiminin düşük olduğu Tosya- Kargı arasındaki havzaların aşağı mecralarında düşük Vf değerleri flüvyal sistemin olgunluk durumunu işaret eder. Nitekim saha Pliyosen'e ait akarsu çökelleri ile doldurulmuştur. Aynı zamanda litolojik unsurların düşük dayanımlı kayaçlardan oluşması da bu duruma katkı sağlamıştır.

\subsection{Akarsu Uzunluk - Gradyan İndeksi (SL İndeks)}

Akarsu boyuna profildeki eğim kırıklıklarının tespitinde ve bunların kökenlerinin incelenmesinde ihtiyaç duyulan bu indise

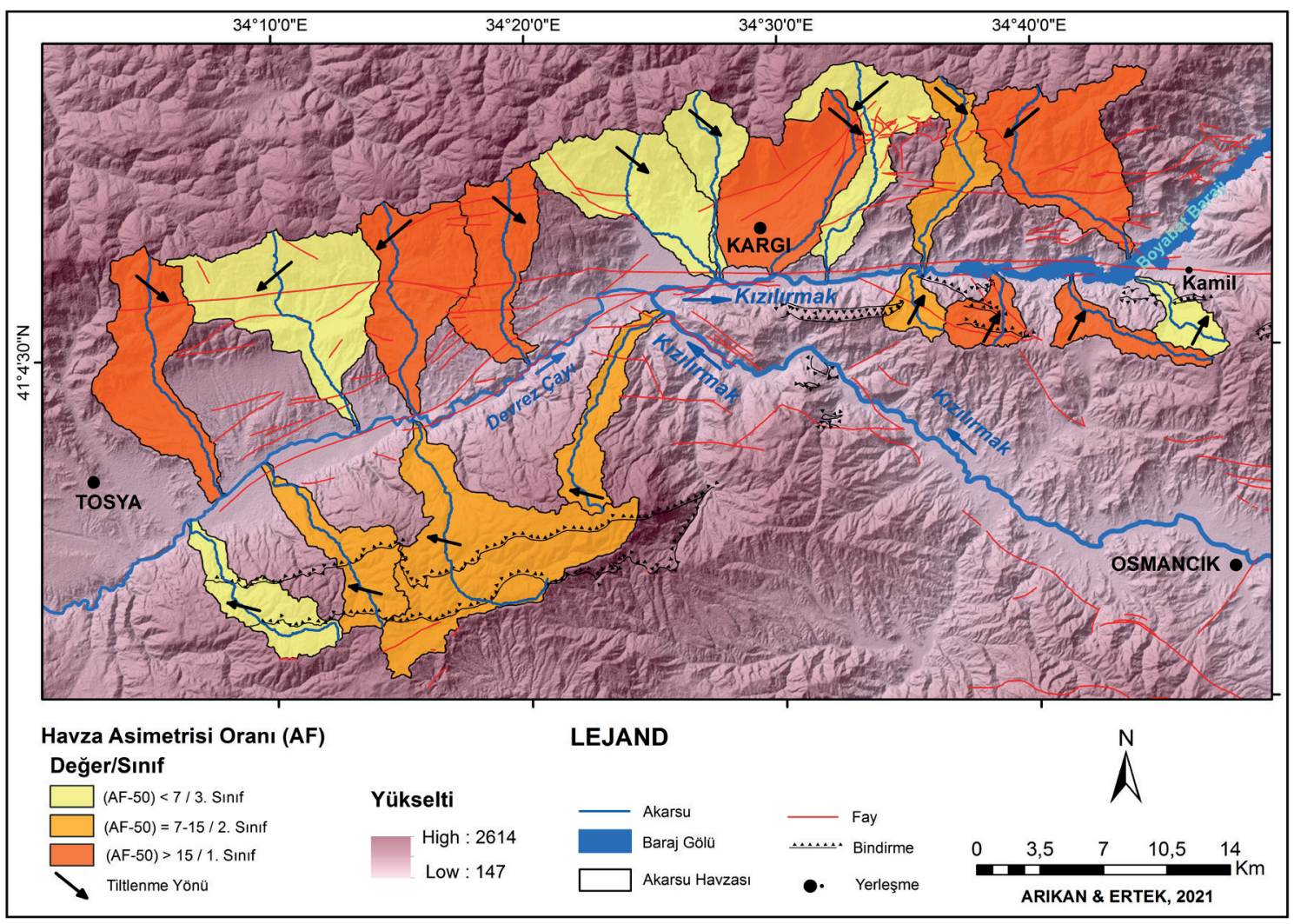

Şekil 4: Kuzey Anadolu Fay Zonu'nun Tosya-Kargı-Kamil arasındaki kesiminde havza asimetrisine göre tektonik aktivite sınıfları haritası. Figure 4: Map of the tectonic activity classes according to basin asymmetry in the part of North Anatolia Fault Zone along Tosya-Kargı and Kamil line. 
Tablo 5: Kuzey Anadolu Fay Zonu'nun Tosya-Kargı-Kamil arasındaki kesiminde akarsu havzalarının farklı mecralarındaki vadilerden elde edilen Vf indeks değerleri ve bu değerlere göre sınıflandırılmış tektonik aktivite düzeyleri.

Table 5: Vf index values obtained from valleys in different parts of the creek basins in the section of the North Anatolian Fault Zone along Tosya-Kargı and Kamil line and tectonic activity levels classified according to these values.

\begin{tabular}{|c|c|c|c|c|c|c|c|}
\hline Havza No & Profil Adı & Vfw & Erd & Eld & Esc & Vf_Degeri & Aktivite Sınıfı \\
\hline & Gökçeyiz Dere_1 & 287,00 & 690 & 675 & 621 & 4,67 & Düşük \\
\hline \multirow[t]{3}{*}{1} & Gökçeyiz Dere_2 & 245,00 & 873 & 910 & 789 & 2,39 & Düşük \\
\hline & Gökçeyiz Dere_3 & 78,00 & 1290 & 1220 & 1120 & 0,58 & Orta \\
\hline & Avlu Çayı_1 & 300,00 & 700 & 700 & 610 & 3,33 & Düşük \\
\hline \multirow[t]{2}{*}{2} & Avlu Çayı_2 & 142,00 & 980 & 1000 & 740 & 0,57 & Orta \\
\hline & Avlu Çayı_3 & 13,00 & 1260 & 1250 & 1160 & 0,14 & Yüksek \\
\hline \multirow[t]{4}{*}{3} & Uğuz Dere_1 & 117,00 & 780 & 780 & 640 & 0,84 & Orta \\
\hline & Uğuz Dere_2 & 22,00 & 1000 & 1170 & 890 & 0,11 & Yüksek \\
\hline & Uğuz Dere_3 & 24,00 & 1440 & 1430 & 1370 & 0,37 & Yüksek \\
\hline & Mezel Dere_1 & 70,00 & 700 & 700 & 590 & 0,64 & Orta \\
\hline \multirow[t]{3}{*}{4} & Mezel Dere_2 & 33,00 & 920 & 885 & 830 & 0,46 & Yüksek \\
\hline & Mezel Dere_3 & 17,00 & 1500 & 1460 & 1392 & 0,19 & Yüksek \\
\hline & Akkese Deresi_1 & 135,00 & 800 & 725 & 583 & 0,75 & Orta \\
\hline \multirow[t]{3}{*}{5} & Akkese Deresi_2 & 55,00 & 911 & 1050 & 802 & 0,31 & Yüksek \\
\hline & Akkese Deresi_3 & 31,00 & 1230 & 1250 & 1216 & 1,29 & Düşük \\
\hline & Kara Dere_1 & 64,00 & 790 & 840 & 580 & 0,27 & Yüksek \\
\hline \multirow[t]{3}{*}{6} & Kara Dere_2 & 52,00 & 1380 & 1710 & 850 & 0,07 & Yüksek \\
\hline & Kara Dere_3 & 58,00 & 1460 & 1450 & 1360 & 0,61 & Orta \\
\hline & İn Deresi_1 & 40,00 & 680 & 660 & 600 & 0,57 & Orta \\
\hline \multirow[t]{3}{*}{7} & İn Deresi_2 & 87,00 & 890 & 900 & 830 & 1,34 & Düşük \\
\hline & İn Deresi_3 & 22,00 & 1100 & 1204 & 1074 & 0,28 & Yüksek \\
\hline & Pelitözü Dere_1 & 95,00 & 710 & 620 & 600 & 1,46 & Düşük \\
\hline \multirow[t]{3}{*}{8} & Pelitözü Dere_2 & 42,00 & 1010 & 1000 & 910 & 0,44 & Yüksek \\
\hline & Pelitözü Dere_3 & 47,00 & 1200 & 1090 & 1030 & 0,41 & Yüksek \\
\hline & Kuru Dere_1 & 9,00 & 684 & 689 & 501 & 0,05 & Yüksek \\
\hline \multirow[t]{3}{*}{9} & Kuru Dere_2 & 25,00 & 1160 & 1150 & 990 & 0,15 & Yüksek \\
\hline & Kuru Dere_3 & 21,00 & 1534 & 1440 & 1350 & 0,15 & Yüksek \\
\hline & Dedeyurdu Dere_1 & 106,00 & 690 & 690 & 456 & 0,45 & Yüksek \\
\hline \multirow[t]{3}{*}{10} & Dedeyurdu Dere_2 & 65,00 & 860 & 830 & 630 & 0,30 & Yüksek \\
\hline & Dedeyurdu Dere_3 & 15,00 & 1240 & 1330 & 1100 & 0,08 & Yüksek \\
\hline & Süpürgelik Dere _1 & 345,00 & 513 & 464 & 410 & 4,39 & Düşük \\
\hline \multirow[t]{3}{*}{11} & Süpürgelik Dere_2 & 41,00 & 660 & 670 & 540 & 0,33 & Yüksek \\
\hline & Süpürgelik Dere_3 & 21,00 & 920 & 920 & 860 & 0,35 & Yüksek \\
\hline & Sarıyar Dere_1 & 15,00 & 540 & 560 & 502 & 0,31 & Yüksek \\
\hline \multirow[t]{3}{*}{12} & Sarıyar Dere_2 & 32,00 & 793 & 790 & 730 & 0,52 & Orta \\
\hline & Sarıyar Dere_3 & 30,00 & 1030 & 972 & 927 & 0,41 & Yüksek \\
\hline & Maksutlu Çayı_1 & 94,00 & 510 & 458 & 392 & 1,02 & Düşük \\
\hline \multirow[t]{3}{*}{13} & Maksutlu Çayı_2 & 58,00 & 610 & 591 & 458 & 0,41 & Yüksek \\
\hline & Maksutlu Çayı_3 & 22,00 & 740 & 745 & 640 & 0,21 & Yüksek \\
\hline & Derdeme Çayı_1 & 91,00 & 540 & 590 & 399 & 0,55 & Orta \\
\hline \multirow[t]{3}{*}{14} & Derdeme Çayı_2 & 43,00 & 750 & 726 & 575 & 0,26 & Yüksek \\
\hline & Derdeme Çayı_3 & 45,00 & 880 & 904 & 826 & 0,68 & Orta \\
\hline & Eminlik Dere_1 & 23,00 & 758 & 870 & 600 & 0,11 & Yüksek \\
\hline \multirow[t]{3}{*}{15} & Eminlik Dere_2 & 36,00 & 1135 & 1125 & 930 & 0,18 & Yüksek \\
\hline & Eminlik Dere_3 & 37,00 & 1530 & 1570 & 1490 & 0,62 & Orta \\
\hline & Geyikli Dere_1 & 29,00 & 1021 & 932 & 740 & 0,12 & Yüksek \\
\hline \multirow[t]{3}{*}{16} & Geyikli Dere_2 & 23,00 & 1520 & 1430 & 1292 & 0,13 & Yüksek \\
\hline & Geyikli Dere_3 & 72,00 & 1770 & 1650 & 1470 & 0,30 & Yüksek \\
\hline & Eldes Dere_1 & 23,00 & 660 & 680 & 600 & 0,33 & Yüksek \\
\hline \multirow[t]{3}{*}{17} & Eldes Dere_2 & 26,00 & 1220 & 1225 & 1050 & 0,15 & Yüksek \\
\hline & Eldes Dere_3 & 77,00 & 1460 & 1520 & 1340 & 0,51 & Orta \\
\hline & Kolluca Dere_1 & 8,00 & 950 & 1065 & 810 & 0,04 & Yüksek \\
\hline \multirow[t]{2}{*}{18} & Kolluca Dere_2 & 50,00 & 1320 & 1330 & 1210 & 0,43 & Yüksek \\
\hline & Kolluca Dere_3 & 27,00 & 1500 & 1510 & 1380 & 0,22 & Yüksek \\
\hline
\end{tabular}


göre eğim kırıklığı litolojik kökenli değilse genel olarak tektonik etkilerin varllğı üzerinde durulur. Mahmood ve Glaugen (2012)'e göre SL indeks değerlerinin tektonik aktivite derecelerine göre sınıflamasında kullanılan eşik değerlerine göre $\mathrm{SL}>535$ ise 1. derece aktivite, $\mathrm{SL}=370-534$ ise 2 . derece tektonik aktivite, $\mathrm{SL}<370$ ise 3. derece tektonik aktivite sınıfında olduğu kabul edilir. Ancak doğrultu atımlı fay etkinliğinin hakim olduğu sahalarda düşey yönlü aktivitenin olamaması ya da daha az olması SL indeks değerlerinde zayıf tektonik etkinliği işaret eden değerlerin ortaya çıkmasına neden olmaktadır. Bu nedenle sahada doğrultu atımlı tektonik rejimin etkisiyle yüksek SL indeks değerlerine yansıyan tektonizmanın rolü sınırlıdır. Buna rağmen incelenen 18 akarsu boyuna profilinin 11'inde SL indeks ortalaması yüksek bulunmuştur (Tablo 6).

Yüksek değerlerin ortaya çıkmasında çoğunlukla litolojik etki belirgindir. Bununla birlikte litolojik bakımdan homojen olan Kös Dağı üzerindeki akarsular yer yer bindirme ve fayları kesmiş ve bu alanlarda SL indeks değerlerinin yükselmiştir. Bu nedenle Kös Dağı kuzey yamaçlarındaki SL indeks değerleri artışında tektonik etkinin varlığı anlaşılmaktadır.

Düşük SL indeks değerleri gösteren ve Tosya yakınlarında Devrez Çayı'na kuzeyden bağlanan yan derelerde diğer parametrelerde de olduğu gibi flüvyal sistemin belli bir olgunluk düzeyine ulaştı̆̆ akarsu boyuna profilde belirgin eğim kırıklıklarının çok az olduğu anlaşılmaktadır. Yine Ada Dağı üzerindeki Süpürgelik Dere, Sarıyar Dere, Maksutlu Dere gibi akarsuların boyuna profillerinde genel olarak düşük SL indeks değerlerine rastlanılmıştır. Karg1 doğusunda Saraycık Dağı üzerindeki akarsularda yüksek SL indeks değerleri elde edilen noktalar ile fayların kesiştiği görülmektedir (Şekil 5).

\subsection{Rölatif Tektonik Aktivite İndeksi (IRAT)}

Sahada uygulanan tüm jeomorfometrik indis değerlerinin ifade ettiği tektonik aktivite derecelerinin ortalamasının alınarak yeniden sinıflandırılmasıyla elde edilen Rölatif Tektonik Aktivite İndeksi Elhamdouni vd., (2008) tarafından 4 sınıfa ayrılmıştır. Buna göre IRAT $<1,5$ çok yüksek aktivite, IRAT=1,5-2,0 yüksek aktivite, IRAT $=2,0-2,5$ orta düzey aktivite, IRAT $>2,5$ zayıf aktivite olarak önerilmiş eşik değerleridir. Bu indise göre çalışma alanındaki 18 havzanın 12 sinde yüksek veya çok yüksek tektonik aktivite derecesine, 4 havzada orta düzey aktivite, 2 havzada ise zayıf aktivite düzeyine ulaşılmıştır (Tablo 7).

Rölatif tektonik Aktivite düzeyinin en yüksek olduğu sahanın genel olarak Kös Dağı kütlesi üzerindeki havzalar olduğu anlaşılmaktadır (Şekil 6). Bunlardan Eminlik Dere Havzası çalışma alanı içindeki "Çok Yüksek Rölatif Tektonik Aktivite Sinıfinda" yer alan tek havzadır. Bu durum diğer indislerin analizinde de değinildiği üzere Kös Dağı kütlesini doğudan sınırlandıran sağ yanal doğrultu atım bileşenli ve verev atımlı normal faylardan oluşan Dodurga Hacıhamza Fay Zonu'nun jeomorfometrik parametreler üzerindeki etkisi olarak değerlendirilmiştir. Ancak bazı havzaların KAF Zonu içinde yer

Tablo 6: Kuzey Anadolu Fay Zonu'nun Tosya-Kargı-Kamil arasındaki kesiminde akarsuların SL İndeks değerleri ve bu değerlere göre sınıflandırılmış tektonik aktivite düzeyleri.

Table 6: SL Index values of creeks in the part of North Anatolian Fault Zone along Tosya-Kargı-Kamil line and tectonic activity levels created according to these values.

\begin{tabular}{|c|c|c|c|c|}
\hline Havza No & Havza Adı & $\begin{array}{l}\text { Maksimum } \\
\text { SL değeri }\end{array}$ & $\begin{array}{l}\text { Ortalama } \\
\text { SL değeri }\end{array}$ & $\begin{array}{l}\text { Aktivite } \\
\text { Derecesi }\end{array}$ \\
\hline 1 & Gökçeyiz Dere Havzası & 857,02 & 349,09 & Düşük \\
\hline 2 & Avlu Çayı Havzası & 1508,33 & 489,66 & Orta \\
\hline 3 & Uğuz Dere Havzası & 1046,89 & 436,15 & Orta \\
\hline 4 & Mezel Dere Havzası & 1827,62 & 613,44 & Yüksek \\
\hline 5 & Akkese Dere Havzası & 1438,77 & 469,81 & Orta \\
\hline 6 & Kara Dere Havzası & 6430,90 & 1008,56 & Yüksek \\
\hline 7 & İn Dere Havzası & 1347,89 & 464,25 & Yüksek \\
\hline 8 & Pelitözü Dere Havzası & 3574,50 & 605,19 & Yüksek \\
\hline 9 & Kuru Dere Havzası & 3096,19 & 795,82 & Yüksek \\
\hline 10 & Dedeyurdu Dere Havzası & 4739,20 & 703,54 & Yüksek \\
\hline 11 & Süpürgelik Dere Havzası & 858,61 & 323,40 & Düşük \\
\hline 12 & Sarıyar Dere Havzası & 791,91 & 377,99 & Düşük \\
\hline 13 & Maksutlu Çayı Havzası & 999,17 & 369,19 & Düşük \\
\hline 14 & Derdeme Çayı Havzası & 2889,17 & 567,24 & Yüksek \\
\hline 15 & Eminlik Dere Havzası & 4961,00 & 991,32 & Yüksek \\
\hline 16 & Geyikli Dere Havzası & 11636,11 & 1473,65 & Yüksek \\
\hline 17 & Eldes Dere Havzası & 1719,76 & 622,45 & Yüksek \\
\hline 18 & Kolluca Dere Havzası & 4275,31 & 1074,76 & Yüksek \\
\hline
\end{tabular}




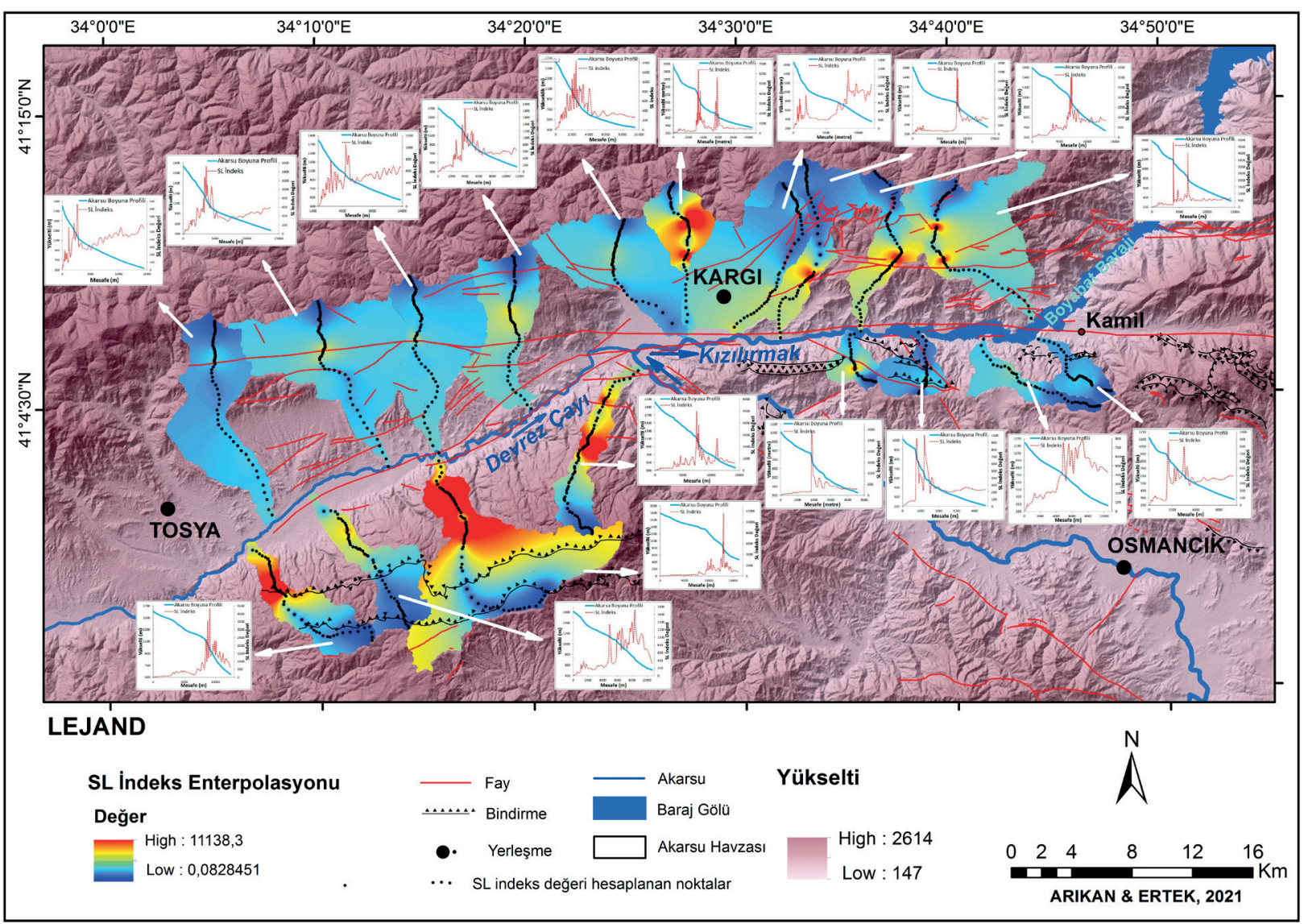

Şekil 5: Kuzey Anadolu Fay Zonu'nun Tosya-Kargı-Kamil arasındaki kesiminde akarsuların SL indeks değerlerinin enterpolasyonu haritası.

Figure 5: Interpolation map of the SL index values of streams in the part of North Anatolian Fault Zone along Tosya-Kargı and Kamil.

Tablo 7: Kuzey Anadolu Fay Zonu'nun Tosya-Kargı-Kamil arasındaki kesiminde akarsu havzalarının Rölatif Tektonik Aktivite sınıfları ve bu sınıflamaya göre oluşturulmuş tektonik aktivite düzeyleri.

Table 7: Relay Tectonic Activity classes of creek basins in the part of North Anatolia Fault Zone along Tosya-Kargı-Kamil and tectonic activity levels established according to this class.

\begin{tabular}{|c|c|c|c|c|c|c|c|c|c|c|}
\hline No & Havza Adı & BS & AF & SL & HI & Smf & Vf & IAT Ort. & IRAT SınıfI & IRAT Derecesi \\
\hline 1 & Gökçeyiz Dere Havzası & 2 & 1 & 3 & 2 & 2 & 3 & 2,16 & 3 & Orta Aktivite \\
\hline 2 & Avlu Çayı Havzası & 3 & 3 & 2 & 2 & 3 & 3 & 2,66 & 4 & Düşük Aktivite \\
\hline 3 & Uğuz Dere Havzası & 3 & 1 & 2 & 2 & 2 & 1 & 1,83 & 2 & Yüksek Aktivite \\
\hline 4 & Mezel Dere Havzası & 3 & 1 & 1 & 2 & 3 & 1 & 1,83 & 2 & Yüksek Aktivite \\
\hline 5 & Akkese Dere Havzası & 3 & 3 & 2 & 2 & 3 & 2 & 2,50 & 3 & Orta Aktivite \\
\hline 6 & Kara Dere Havzası & 3 & 3 & 1 & 1 & 2 & 1 & 1,83 & 2 & Yüksek Aktivite \\
\hline 7 & İn Dere Havzası & 3 & 1 & 1 & 3 & 1 & 2 & 1,83 & 2 & Yüksek Aktivite \\
\hline 8 & Pelitözü Dere Havzası & 3 & 3 & 1 & 1 & 3 & 2 & 2,16 & 3 & Orta Aktivite \\
\hline 9 & Kuru Dere Havzası & 3 & 2 & 1 & 1 & 3 & 1 & 1,83 & 2 & Yüksek Aktivite \\
\hline 10 & Dedeyurdu Dere Havzası & 3 & 1 & 1 & 1 & 3 & 1 & 2,0 & 2 & Yüksek Aktivite \\
\hline 11 & Süpürgelik Dere Havzası & 3 & 3 & 3 & 2 & 3 & 3 & 2,83 & 4 & Düşük Aktivite \\
\hline 12 & Sarıyar Dere Havzası & 3 & 1 & 3 & 2 & 2 & 1 & 2,50 & 3 & Orta Aktivite \\
\hline 13 & Maksutlu Çayı Havzası & 3 & 1 & 3 & 1 & 2 & 2 & 2,0 & 2 & Yüksek Aktivite \\
\hline 14 & Derdeme Çayı Havzası & 3 & 2 & 1 & 1 & 2 & 2 & 1,83 & 2 & Yüksek Aktivite \\
\hline 15 & Eminlik Dere Havzası & 1 & 2 & 1 & 1 & 2 & 1 & 1,33 & 1 & Çok Yüksek Aktivite \\
\hline 16 & Geyikli Dere Havzası & 3 & 2 & 1 & 1 & 2 & 1 & 1,66 & 2 & Yüksek Aktivite \\
\hline 17 & Eldes Dere Havzası & 3 & 2 & 1 & 1 & 3 & 1 & 1,83 & 2 & Yüksek Aktivite \\
\hline 18 & Kolluca Dere Havzası & 2 & 3 & 1 & 1 & 3 & 1 & 1,83 & 2 & Yüksek Aktivite \\
\hline
\end{tabular}




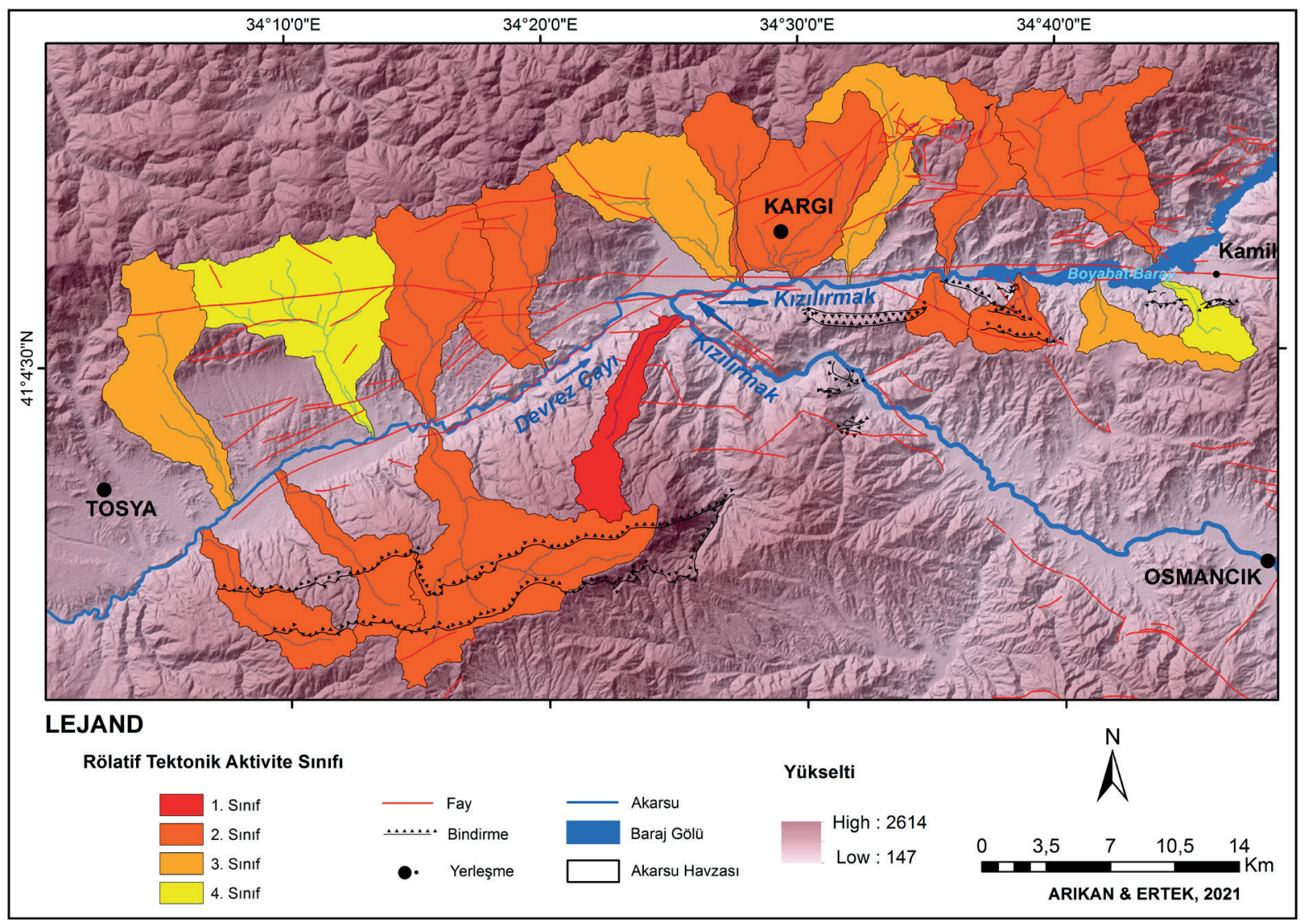

Şekil 6: Kuzey Anadolu Fay Zonu'nun Tosya-Kargı-Kamil arasındaki kesiminde akarsu havzalarının Rölatif Tektonik Aktivite Sınıfları haritası.

Figure 6: Map of The Relative Tectonic Activity Classes of creek basins in the part of North Anatolia Fault Zone along Tosya-Kargı and Kamil.

almasına rağmen "Düşük Rölatif Tektonik Aktivite Sınıfında" olduğu anlaşılmıştır. Bunlardan ikisi Tosya yakınlarındaki Avlu Çayı ve Kamil yakınlarındaki Süpürgelik Dere havzalarıdır. Bu havzalarda flüvyal sistemin olgunluk düzeyini temsil eden jemorfometrik parametreler elde edilmiştir. Nitekim Karg1Tosya arasında erken (Neojen) kurulmuş drenaj sisteminin varlığını işaret eden sedimantolojik unsurlar mevcuttur.

\section{SONUÇ}

Kuzey Anadolu Fay Zonu'nun Tosya-Karg1-Kamil arasındaki kesiminde Ilgaz Dağları'nın güney yamaçlarından ve Kös Dağı'nın kuzey yamaçlarından Devrez Çayı'na akaçlanan drenaj havzaları ile Saraycık Dağı'nın güney yamaçları ve Ada Dağı'nın kuzey yamaçlarından Kızılırmak'a akaçlanan havzaların sayısal yükseklik modellerinden yararlanarak jeomorfometrik analizleri yapılmış ve sahanın göreli tektonik aktivite düzeyleri belirlenmiştir. Bu kapsamda çalışma alanında seçilen 18 drenaj havzasının Hipsometrik İntegral ve Eğrisi (HI ve HE), Dă̆ Cephesi Sinüselliği (Smf), Havza Şekil İndeksi (Bs), Havza Asimetrisi (AF), Vadi tabanı genişliği-Vadi Yamaç Yüksekliği
Oranı (Vf) ve Akarsu Uzunluk-Gradyan İndeksi (SL) değerleri ayrı ayrı hesaplanmış ve elde edilen sonuçlardan Rölatif Tektonik Aktivite Sinıfları oluşturulmuştur.

Jeomorfometrik indislerden elde edilen sonuçlar, çalışma alandaki göreli tektonik etki düzeyinin kısa mesafede değiştiğini göstermektedir. Sahanın jeomorfometrik indislerinin ifade ettiği tektonik aktivite düzeylerinin oluşmasında Kuzey Anadolu Fay Sistemi'nin doğrultu atım tektoniği ile birlikte özellikle güney bloktaki Kös ve Ada Dağı kütleleri arasındaki sağ yanal doğrultu atım bileşenli verev atımlı normal faylardan oluşan DodurgaHacıhamza Fay Zonu'nun belirleyici unsur olduğu anlaşılmaktadır. Genel olarak KAF'ın güney bloğunda yer alan havzalarda tektonik etki jeomorfometrik parametrelerde daha belirgin iken bu etki Kuzey bloktaki Ilgaz Dağları ve Saraycık Dağı üzerindeki havzalarda daha azdır. Kös Dağı gibi litolojik bakımdan daha homojen olan kesimler yanında Ilgaz Dağları gibi daha karmaşık litolojiler sunan kesimlerin varlığı jeomorfometrik parametreleri etkileyen unsurlar olmuştur. Kuzeyde özellikle Ilgaz Dağları kesimindeki havzalarda yüzeyin şekillenmesinde litolojinin etkisi belirgindir. 
Karg1 kuzeydoğusunda Saraycık Dağ1 kütlesi üzerindeki Pelitözü Dere, Kuru Dere ve Dedeyurdu Dere havzalarında düşük Vf değerleri, yüksek hipsometrik integral değerleri ve yüksek SL indeks değerlerine rastlanılmıştır. Benzer şekilde Karg1 güneybatısında Kös Dağı üzerindeki Eminlik Dere, Geyikli Dere, Eldes Dere ve Kolluca Dere havzalarında düşük Vf değerleri, yüksek hipsometrik integral değerleri ve yüksek SL indeks değerlerine rastlanılmıştır. İndislerin ortaya koyduğu bu parametreler yüksek tektonik etkinliği ve sahanın hızlı yükselimini işaret eder.

Sahada uygulanan tüm jeomorfometrik indis değerlerinin ifade ettiği tektonik aktivite derecelerinin ortalamasının alınarak yeniden sınıflandırılmasıyla elde edilen Rölatif Tektonik Aktivite İndisine göre çalışma alanındaki 18 havzanın 12 sinde yüksek veya çok yüksek tektonik aktivite derecesine, 4 havzada orta düzey aktivite, 2 havzada ise zayıf aktivite düzeyine ulaşılmıştır. Rölatif Tektonik Aktivite düzeyinin en yüksek olduğu sahanın genel olarak Kös Dağı kütlesi üzerindeki havzalar olduğu bunlardan Eminlik Dere Havzası çalışma alanı içindeki "Çok Yüksek Rölatif Tektonik Aktivite Sınıfında" yer alan tek havza olduğu anlaşılmaktadır. Bu durum diğer indislerin analizinde de değinildiği üzere Kös Dağı kütlesini doğudan sınırlandıran sağ yanal doğrultu atım bileşenli ve verev atımlı normal faylardan oluşan Dodurga Hacıhamza Fay Zonu'nun jeomorfometrik parametreler üzerindeki etkisi olarak değerlendirilmiştir. Ancak bazı havzaların KAF Zonu içinde yer almasına rağmen "Düşük Rölatif Tektonik Aktivite Sınıfında" olduğu görülmektedir. Bunlardan ikisi Tosya yakınlarındaki Avlu Çayı ve Kamil yakınlarındaki Süpürgelik Dere havzalarıdır. Bu havzalarda flüvyal sistemin olgunluk düzeyini temsil eden jeomorfometrik parametreler elde edilmiş̧ir.

Tosya-Karg1-Kamil hattında Devrez-Kızılırmak vadilerinin, sedimantolojik unsurlarının faylarla ilişkisi, paleoakıntının yönü ve vadi morfometrisi; burada flüvyal sistemin fay kontrolünde, ilksel yatağın, bu günkünden daha kuzeyde, Ilgaz ve Saraycık kütleleri üzerinde kurulduğunu ve zamanla güneye göç ederek Kös Dağı, Ada Dağ eteklerine yaklaştığını ve böylece tektonik oluğun asimetrik bir vadi görünümü aldığı anlaşılmaktadır.

Kızılırmak'in Osmancık ve Kargı (Hacıhamza) arasında GD$\mathrm{KB}$ istikametinden sapması ve KAF Zonu'nda B-D yönlü Devrez Çayı'na bağlanarak, Devrez Çayı Vadisi'nin genel uzanımına uyması, KAF Zonu'nda Devrez-Kızılırmak oluğunun daha eski (Pliyosen) alüvyonların içermesi, KAF Zonu girişi öncesi ile KAF Zonu içindeki vadilerinin morfometrik özelliklerinin farklılığı gibi veriler Devrez Çayı drenajının daha erken kurulduğunu ve Kızılırmak'ı kaptı̆̆ını işaret eder. Çalışma alanı güneyini de kapsayan araştırmalarımızda başlangıçta Oğuzlar'dan güneye, Orta Anadolu göl sistemine, akaçlanan Kızılırmak Havzası'nın Laçin-Hacıhamza arasında Devrez'in kolu olan bir akarsuya kapılmak suretiyle Devrez Çayı'na bağlandığını göstermektedir. Özetle Kızılırmak'ın başlangıçta Laçin-Osmancık-Hacıhamza hattında yaklaşık $60 \mathrm{~km}$ uzunlukta Devrez Çayı'nın kolu olan bir dere olduğu anlaşılmaktadır.

Hakem Değerlendirmesi: Dış bağımsız.

Çıkar Çatışması: Yazarlar çıkar çatışması bildirmemiş̧ir

Finansal Destek: Yazarlar bu çalışma için finansal destek almadığını beyan etmiş̧tir.

Peer-review: Externally peer-reviewed.

Conflict of Interest: The authors have no conflict of interest to declare.

Grant Support: The authors declared that this study has received no financial support.

\section{KAYNAKÇA/REFERENCES}

Akkan, E. (1970). Bafra Burnu-Delice kavşağı arasında kızılırmak vadisi'nin jeomorfolojisi, Ankara Üniv. DTCF. Yay. No 191, Ankara.

Akkuş, A. (1980). Devrez Çayı Vadisi'nin jeomorfolojisi. Karadeniz Teknik Üniversitesi Yer Bilimleri Fakültesi Yayınları, Yayın No: 24, Trabzon.

Arıkan, M. (2020). Kızılırmak Havzası'nın Uğurludağ-Bayat-KargıOsmancık Arasındaki Kesiminin Jeomorfolojisi (Çorum). Yayınlanmamış Doktora Tezi, İst. Üniv. Sos. Bil. Enst. 414 s.

Bull, W. B. (2007). Tectonic Geomorphology of Mountains, a New Approach to Paleoseismology, Oxford: Blackwell Publishing.

Bull, W. B., Mcfadden, L. D. (1977). Tectonic Geomorphology North and South of the Garlock Fault, California, Geomorphology in Arid Regions, Proceedings of the Eight Annual Geomorphology Symposium (Ed. D. O. Doehring), pp: 115-138, USA: State University of New York at Binghamton, Binghamton, NY.

Dewey, J.F., Hempton, M.R., Kidd, W.S.F., Şaroğlu, F. and Şengör, A.M.C. (1986). Shortening of Continental Lithosphere: The Neotectonics of Eastern Anatolia - A Young Collisional Zone, In: Coward, M.P. and Ries, A.C. (eds) Collision Tectonics, Geol. Soc. Spec. Publ., 19, 3-36.

Elhamdouni, R., Irigaray, C., Fernandez, T., Chacón, J., Keller, E. A. (2008). Assessment of Relative Active Tectonics, Southwest Border of Sierra Nevada (Southern Spain), Geomorphology, 96, 150-173.

Hack, J.T. (1973). Stream profile analysis and stream gradient index. Journal of Research of the United States Geological Survey, 1 (4), 421-429.

Keller, E.A. and Pinter, N. (1996). Active tectonics, earthquake uplift and landscape. Prentice Hall, Upper Saddle River.

Keller, E. A. and Pinter, N. (2002). Active tectonics, earthquakes, uplift and landscape, Second Edition, Prentice Hall, Upper Saddle River, $362 \mathrm{p}$. 
Ketin, İ. (1983). Türkiye Jeolojisine Genel Bir Bakış; İTÜ Yayını 1259; 595 s, İstanbul.

Koçyiğit, A. (2007). Kızılırmak Kargı (Geyiktepe) Barajı ve HES yeri aktif tektonik araştırması final raporu, ODTÜ Müh. Fak. Ankara.

Leopold, B., Wolman, M.G., (1957). River Channel Patterns: Braided, Meandering and Straight, U.S. Geol. Surv. Prof. Pap. 282B, 39-85.

Mahmood, S. A., Gloaguen, R., (2012). Appraisal of Active Tectonics in Hindu Kush: Insights from DEM derived geomorphic indices and drainage analysis, Geoscience Frontiers, V. 3 (4), p. 407-428.

McKenzie, D. P. (1972). Active tectonics of the Mediterranean region. Geophysical Journal of the Royal Astronomical Society, 30, 109185.

Över, S. (1999). Kuzey Anadolu Fay Zonu'nun orta ve batı kesiminde bölgesel gerilme durumunun incelenmesi, Türkiye Jeoloji Bülteni Cilt 42/1 s. 85-96.

Özalp, S., Emre, Ö. ve Doğan, A., (2013). Kuzey Anadolu Fayı Güney Kolu'nun Segment Yapısı ve Gemlik Fayının Paleosismik Davranışı, Kb Anadolu, Maden Tetkik ve Arama Dergisi, 147: 1 - 17.

Selby, M.J. (1980). A rock mass strength classification for geo morphic purposes: with tests from Antarctica and New Zealand. Zeitschrift fur Geomorphologie, 24: 31-51.

Strahler, A.N. (1952). Hypsometric (area-altitude) analysis of erosional topography, Bull. of the Geological Soc. of America No. 63, p. 1117-1142.

Şengör A.M.C. (1995). Sedimentation and tectonics of fossil rifts. In Tectonics of Sedimentary Basins, ed. CJ Busby, RV Ingersoll, pp. 53-117. Oxford: Blackwell.

Şengör, A.M.C. ve Y1lmaz, Y., (1981). Tethyan evalution of Turkey: A plate Tectonic approach, Tectonophysics, 75, 11-241.
Tüysüz, O. (1985). Karg1 masifi ve dolayındaki tektonik birliklerin ayırdı ve araştırılması (petrolojik inceleme), Doktora Tezi, İstanbul Üniversitesi, Fen Bilimleri Enstitüsü, $431 \mathrm{~s}$.

Tüysüz, O., (2017). tosya ile havza arasındaki bölgenin morfolojik gelişiminde kuzey anadolu fayının etkileri, 70. Türkiye Jeoloji Kurultayı Bildiri Özleri, s. 584-585.

Tüysüz, O. ve Dellaloğlu, A.A. (1994). Orta Anadolu'da Çankırı Havzası ve Çevresinin Erken Tersiyer'deki Paleocoğrafik Evrimi, Türkiye 10. Petrol Kongresi Bildiriler Kitab1, 56-75.

Tüysüz, O. ve Erturaç, M. K. (2005). Kuzey Anadolu Fayı'nın Devrez Çayı ile Soruk Çayı Arasındaki Kesiminin Özellikleri ve Fayın Morfolojik Gelişimindeki Etkileri, Türkiye Kuvaterner Sempozyumu TURQUA-V, s.26-40, İstanbul.

Tüysüz, O. and Yiğitbaş, E., (1994). The Karakaya Basin: A PalaeoTethyan marginal basin and its age of opening. Acta Geol. Hungarica, 37/3-4, 327-350.

Uğuz, M. F., Sevin, M., (2009). 1/100 000 Ölçekli türkiye jeoloji haritaları, No 114, F 32 Paftası, MTA Jeoloji Etütleri Dairesi Ankara.

Yıldırım, C. (2008). Almacık bloku ve yakın çevresinin morfotektoniği, İTÜ Avrasya Yerbilimleri Enstitüsü, Doktora Tezi.

Yıldırım, C., Tüysüz, O., (2009) Blok rotasyonuna fluviyal tepkinin nicel analizi: almacık bloku örneği, İÜ̈ Dergisi, Cilt 8, Sayı 3: 120130.

Yılmaz, Y. ve Tüysüz, O. (1984). Kastamonu - Boyabat - Vezirköprü Tosya Arasındaki Bölgenin Jeolojisi (Ilgaz - Karg1 Masifinin Etüdü), MTA Rap. No 7838. 